\title{
Analysis of Merger and Acquisition Deals of Major Indian Banks: An Event Based Study
}

Effulgence

Vol. 16 No. 1 (Special Issue 2)

January - June, 2018 Rukmini Devi Institute of Advanced Studies

E-mail : effulgence@rdias.ac.in, Website : www.rdias.ac.in

http://effulgence.rdias.ac.in/user/default.aspx

https://dx.doi.org/10.33601/effulgence.rdias/v16/iSpl2/2018/82-120

\section{Dr. Anjala Kalsie ${ }^{1}$ \\ Dr. Ashima Arora (Corresponding Author) ${ }^{2}$}

\begin{abstract}
The paper studies the Merger and Acquisition phenomenon on both the acquiring and the target bank's stock prices of six major domestic bank MEAs, in a period spanning from 2004 to 2014. It compares the short-term impact of acquirer and target share prices around the announcement period. Two different methods - Market Model and Market Adjusted Models were used to find the impact of merger announcement on stock prices. The paper studies the phenomenon, from a time 10 days prior to the merger announcement date, to 10 days post the merger announcement. The paper finds that in case of distressed asset takeover or where the merger was forced by the RBI, both the acquirer and target entities lost value around the day of announcement. Among the six target banks, abnormal returns are marked by large standard deviations, with returns, around the announcement date, ranging from a large $-70 \%$ to $+50 \%$. The study did find significant abnormal returns at four-days post the merger announcement. However, no significant abnormal returns are found for any of the event windows. The paper also finds that abnormal returns gradually vanish, few days after the announcement, supporting the efficient market hypothesis of Fama et al. (1969).
\end{abstract}

Keywords:

\section{INTRODUCTION}

$\mathrm{T}_{\mathrm{i}}$ he study of change in behaviour of entities and investors over the period of time and across extrinsic and intrinsic conditions had been done to better understand the factors driving the underlying value of companies on stock markets. A popular belief endows M\&A as an intelligent strategy to expand distribution channels or enter new markets, allowing the operations to become more synergistic. Owing to prospective encouraging effects of M\&A, their announcement had generally been found to induce wave-effect in the stock market impacting stock prices of the target company. The expectation about the future profit of the company (target) gets revised by the investor post M\&A announcement (Panayides \& Gong, 2002). Keeping with the understanding of impact of M\&A announcement on stock price, the study seek to empirically examine the impact on the stock prices of acquired and acquiring entities. The study undertakes the case of merger of six major banks of India as announced

1. Assistant Professor, Faculty of Management Studies, University of Delhi, kalsieanjala@gmail.com

2. Shaheed Sukhdev College of Business Studies, University of Delhi, ashima.arora@sscbs.du.ac.in 
during the period 2004-2014. The study is unique in the sense that the case involves the analysis of announcement of merger and acquisition of distressed banks with healthy banks.

Event study methodology was adopted to accomplish the objective of the study of empirically examining the impact of announcement by using the stock returns. A statistical tool, event study allows the estimation of impact of any corporate event including stock splits, acquisition announcement, and earnings announcement on stock returns of a company. The paper has been apportioned in five sections. Section 2 deals with review of literature. Objectives and Methodology had been provided in Section 3followed by results in Section 4 and Conclusion, Limitations and Future scope in Section 5.

\section{LITERATURE REVIEW}

Kyriazopoulos \& Drymbetas (2015) reviewed 118 banking M\&As during the period 1996-2010. Their study finds short-term value creation effects for a sample of domestic bank M\&As in the greater European area. The study concludes that domestic bank M\&As, on average, can still create value for the shareholders of the majority of target banks involved in this transaction, with the notable exception of low prior profitability institutions. Consistent with the pertinent literature, it found that positive abnormal returns for targets are existent. Their finding is particularly supported by the 3-day cumulative abnormal returns around the announcement date. Both the market model and market-adjusted model provide sound justification of a positive reaction to the M\&A deal. However, excess returns gradually vanish after the announcement date supporting the efficient market hypothesis of Fama et al. (1969)

Lebedev , Peng, Xie, \& Stevens (2015) evaluated that the impact of merger on the operating performance of acquiring firms in different industries by employing before and after-financial ratio to investigate the impact of merger on firms. All the mergers that took place in public limited and traded companies in India between 1991 and 2003 were selected. The analysis result suggested that there was little variation in terms of impact as operating performance after mergers. M\&A had a slightly positive impact of profitability on pharmaceutical, textiles and electrical equipment sector and showed marginal negative impact on operative performance. Some of the industries had a significant decline both in terms of profitability and return on investment and assets after merger.

Coming down on the various motives for Merger and Acquisitions, Kakani \& Jay (2006) stated that there were multiple reasons for Merger and Acquisitions in the Indian Banking Sector and still contains to capture the interest of a research. Strict control regulations were cited as the primary reason. Further, it may be asserted that customers benefits from Indian structure of banks owing to the immense high competitions amongst the banks but the same factor poses challenge to the level of global Banking Industry. It would not be far from the truth that merger and acquisition is imperative for the state to create few large Banks. R. Srivassan et al., (2009) gave the views on financial implications and problem occurring in Merger and Acquisitions (M\&As). It highlighted the cases for consolidation and discussed the synergy based merger which emphasized that merger is for making the firm size large, but has no guarantee to maximize profitability on a sustained business and there is always the risk of improving performance after merger.

Less notable differences between European and US M\&As, in terms of acquirers' performance, are found in Ismail \& Davidson (2005) who reported minimal but significant returns for acquirers in the $(-2,+2)$ event window for a sample of European transactions. Kalsie \& Kalra (2015) employed residual income approach to investigate value creation for the acquirer after the merger or acquisition undertaken. The study using traditional accounting method found that in the aftermath of acquisition, the profitability declined significantly. In 
similar lines, it was also found that post-acquisition, the fundamental valuation of acquirers appeared to be significantly lower relative to their pre-acquisition position. These results were obtained using residual income approach.

In line with Cybo-Ottone \& Murgia (2000), Ismail \& Davidson (2005) concluded that for the 2-day announcement window $(-1,0)$ domestic M\&As are more profitable than cross-border ones, but abnormal returns for target banks are relatively small. Campa and Hernando (2006) examined the financial industry in Europe during 1998-2002 and found positive short-term returns for target firms around the announcement day, while abnormal returns for bidders were zero.

Kalsie \& Kalra (2015) assessed the impact of mergers and acquisition on operating performance and wealth of shareholders for a period of 2006-2009 for a total of 52 companies. The study used event study methodology along with accounting performance method for examining the hypothesis. Authors found that stock price returns was immune to mergers and acquisition of the firms. Neither the event generated significant impact on firm's operating performance nor could any abnormal returns be created.

Need of Study: None of the studies reviewed were found to explore the impact of merger and acquisition of major Indian banks. Thus, the current study was framed to explore the effect of Merger \& Acquisition on the securities and their prices, trading on stock market of India. The attempt was to estimate if M\&A creates any value for its investors.

\section{OBJECTIVES AND METHODOLOGY}

The study aims to identify the impact of merger and acquisition deal between Indian banks where the target bank is generally forced by Indian central bank, RBI into merger deal. Consequently, the impact was analysed on the acquirer and the target company's stock prices, in three phases - pre-M\&A, on the M\&A announcement date, post-M\&A. The research problem deals with the analysis of announcement of a merger of distressed bank with a healthy public sector bank on their stock prices. The banks, both the target and he acquiring banks that would be studied for their merger and acquisition details including date and deal details has been provided below:

\begin{tabular}{|l|l|l|l|}
\hline Acquiring Bank & Target Bank & $\begin{array}{l}\text { Announcement } \\
\text { Date }\end{array}$ & Deal Details \\
\hline $\begin{array}{l}\text { Oriental Bank of } \\
\text { Commerce }\end{array}$ & $\begin{array}{l}\text { Global Trust } \\
\text { Bank }\end{array}$ & $26^{\text {th }}$ July, 2004 & $\begin{array}{l}\text { Sale of Assets, and residual value to } \\
\text { common share holders }\end{array}$ \\
\hline IDBI & IDBI Bank & $29 / 07 / 2004$ & Share swap ratio at 100:142 ratio \\
\hline IDBI & $\begin{array}{l}\text { United Western } \\
\text { Bank }\end{array}$ & $12 / 09 / 2006$ & $\begin{array}{l}\text { Buyback of UWB shares at Rs. } \\
28 / \text { share }\end{array}$ \\
\hline HDFC Bank & $\begin{array}{l}\text { Centurion Bank } \\
\text { of Punjab }\end{array}$ & $25 / 02 / 2008$ & Rs. 95.26 billion \\
\hline $\begin{array}{l}\text { Kotak Mahindra } \\
\text { Bank }\end{array}$ & Rajasthan & $18 / 05 / 2010$ & Rs. 28.53 billion \\
\hline
\end{tabular}




\section{Methodology}

The study analyses six major Indian Banking merger deals with focus on studying their stock prices, around the merger announcement date. The study, first calculates expected market returns, for 10 prior to 10 days post the merger announcement day. Using this expected market return, it calculates the abnormal returns for the stock. This is done in two phases - 1) for each of two stocks (1 acquiring and 1 target bank) 2) then, a cumulative study, separately for the acquiring bank and the target bank.

Then, Cumulative Average Abnormal returns is calculated for 6 types of event windows, which is as follows - i) $(-10,-1)$ ii) $(-5,-1)$ iii) $(-1,+1)$ iv) $(+1,+5)$ v) $(+1,+10)$. Here $(-a, b)$, would mean a cumulative study between ' $a$ ' days prior to the merger announcement, and $b$ days post the announcement. This is again, done, separately for the acquiring and the target bank. Using the t-statistics, the null hypothesis is either accepted or rejected.

The following alternate hypothesis $\left(\mathrm{H}_{1}\right)$ was developed, namely

$\mathrm{H}_{1}: \mu \neq 0$

The abnormal return is present after the merger announcement date

here, $\mu$, is the population abnormal return for each deal firstly, individually analysis of each. M\&As was done after that a cumulative analysis for 21 days around the announcement period, and finally the event windows was performed.

The above event period analysis is done with the market model assumptions, and the market adjusted assumptions. The study first takes 360 days' share price history of the acquiring and the target bank. The share price is analysed, in three major phases pre-announcement, the day of announcement, and post-announcement analysis.
Regressive Analysis between the stock and benchmark index

The pre-announcement share prices are used to calculate the linear relation between market returns and the stocks actual returns. Bank Nifty is taken as the market benchmark for calculating relation, as the merger considered in this study concerns banking stocks. Hence, it is expected to give the best judgment for expected market return, as against other broad indices such as Nifty50, BSE 30, etc.

The regressive analysis, gives us, a relation of this form -

$R i t=\alpha+\beta^{*} R m t$

where,

$\alpha=$ Intercept of the linear relation between the stock and the benchmark index (Bank Nifty),

$R_{i t}=$ Return of the stock $\mathrm{i}$, at time $\mathrm{t}$,

$R_{m t}=$ Return of Bank Nifty, at time $\mathrm{t}$,

$\beta=$ Slope of the linear relation between the stock and the benchmark index (Bank Nifty)

Also, the standard deviation $(\sigma)$ and R-square value (to determine the significance of correlation between the stock and benchmark index) is calculated for this relation.

\section{Calculation of Abnormal Returns}

Suppose, ' $\mathrm{t}$ ' is the date of merger announcement. The linear relation derived above, is used to calculated the expected return for the time between period $(\mathrm{t}-$ 10) days and $(t+10)$ days, i.e., a total of 21 days, by the formula,

Eit $=\alpha+\beta^{*} R_{i m}$

where, $E_{i t}$ is the expected return of stock $i$, on time $t$ 
The Abnormal Return (AR) values were evaluated in two different models - market model and market adjusted model. For market model, $\alpha$ and $\beta$, will be what, has been calculated above. However, for market adjusted model, $\alpha$ will be 1 , and $\beta$ will be 0 .

Hence the formula for abnormal returns for the two different models, is as follows,

\section{Market Model -}

$$
\mathrm{AR}_{\mathrm{it}}=\mathrm{R}_{\mathrm{it}}-\left(\alpha+\beta^{*} \mathrm{R}_{\mathrm{mt}}\right)
$$

Market Adjusted Model - $\quad \mathrm{AR}_{\mathrm{it}}=\mathrm{R}_{\mathrm{it}}-\mathrm{R}_{\mathrm{mt}}$

After calculating $\mathrm{AR}_{\mathrm{it}}$, with the null hypothesis $\left(\mathrm{H}_{0}\right)$, being,

$\mathrm{H}_{0}: \mu=0$,

$\mathrm{H}_{1}: \mu \neq 0$

where, $\mu$, is the population abnormal return

Now, the $\mathrm{t}$-stat value is computed to determine if the abnormal value is calculated at $95 \%$ confidence interval, with the following formula,

$$
t=\frac{\bar{x}-\mu}{s / \sqrt{n}}
$$

This will be a two-tailed t-test, since the concern regards abnormal returns on either sides of the hypothesized mean. Using appropriate $t$ values, for $90 \%$ confidence interval, the hypothesis is accepted or rejected.

\section{Calculation of Cumulative Abnormal Return (CAR), and event windows}

With the $A R_{i t}$ values, the Cumulative Abnormal Return \% (CAR \%) between two different time period, say $t_{1}$ and $t_{2}$, will be calculated. CAR $\%$ will be the sum of each $\mathrm{AR}_{\mathrm{it},}$, between $\mathrm{t}_{1}$ and $\mathrm{t}_{2}$. Hence,

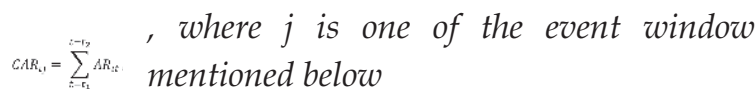

It will be calculated for the following event windows $(\mathrm{t}-10, \mathrm{t}-1)$

$(\mathrm{t}-5, \mathrm{t}-1)$

$(\mathrm{t}-10, \mathrm{t}+10)$

$(\mathrm{t}-1, \mathrm{t}+1)$

$(\mathrm{t}+1, \mathrm{t}+5)$

$(\mathrm{t}+1, \mathrm{t}+10)$
After calculation of CAR\% of each of the stocks, the acquiring and the target companies are separately analyzed into two different groups.

\section{Calculation of Cumulative Average Abnormal Returns (CAAR)}

For each of the acquiring and the target companies, Cumulative Average Abnormal Returns \% (CAAR\%) is calculated as followed,

, where $\mathrm{j}$ is one of the event window mentioned above

$$
\begin{aligned}
C A A R_{j}=\sum_{\forall i} C A R_{i j} & \text { Simply put, } C A A R_{j} \text { is the } \\
& \text { sum of CAR of each of the }
\end{aligned}
$$
banks. After calculating this, t-test will be run on the values, to determine if the results are significant enough, at $95 \%$ confidence interval to reject the Null Hypothesis as mentioned above.

Analysis of Six Major Banks

\section{Result : Analysis interpretation}

1 Oriental Bank of Commerce(OBC) and Global Trust Bank(GTB)

\section{Background and macro analysis of the deal}

Ramesh Geli started GTB in the mid-1990s. As of March 2003, the net worth of the bank was wiped off owing to accumulated losses to the tune of Rs 2.65 billion. If provisions for the entire gross nonperforming assets (NPA) of Rs 9.16 billion would have been made, the accumulated loss would have been Rs 5.52 billion.

Following the failure of the management's repeated attempts to infuse capital in GTB, the RBI placed a moratorium on the bank's operations on July 24, 2003 to protect the depositors' interest. On July 26, 2003 RBI announced the merger of GTB with OBC. This move was aimed to protect the interest of GTB's depositors. 
Major Comparative Performance Analysis

\begin{tabular}{|l|c|c|c|}
\hline Particulars (in Rs.crores) & OBC & GTB & Merged Entity \\
\hline Advances & 15677 & 3276 & 18953 \\
\hline Investments & 14780 & 2650 & 17430 \\
\hline Deposits & 29809 & 6921 & 36730 \\
\hline Net Profit & 457 & -273 & \\
\hline Gross NPA & 1146 & 916 & 873 \\
\hline Net NPA & 225 & 648 & 10.8 \\
\hline Gross NPA(\%) & 6.9 & 25.8 & 4.6 \\
\hline Net NPA(\%) & 1.4 & 19.8 & 12.2 \\
\hline Capital Adequacy Ratio & 14.0 & 0.0 & \\
\hline
\end{tabular}

It is seen that large NPAs was a large issue that OBC had to tackle.

\section{Synergy Benefits}

\begin{tabular}{|c|c|c|c|}
\hline Region & OBC & GTB & Combined \\
\hline North & 691 & 9 & 700 \\
\hline South & $\mathbf{5 2}$ & $\mathbf{5 0}$ & $\mathbf{1 0 2}$ \\
\hline East & $\mathbf{7 4}$ & 5 & 79 \\
\hline West & $\mathbf{1 7 2}$ & $\mathbf{3 9}$ & $\mathbf{2 1 1}$ \\
\hline
\end{tabular}

Still further it is seen that $\mathrm{OBC}$ gained a large presence in the Western and Southern region.

\section{Impact on GTB}

As per the draft scheme of amalgamation, the entire amount of the paid-up capital and reserves of the transferor bank would be treated as provision for bad and doubtful debts and depreciation in other assets. There would be no swap of shares between the shareholders of the bank. The net proceeds from the recovery of bad assets would be utilised to make good the shortfall borne by OBC towards meeting the liability of GTB depositors. Any surplus will be used to make pro-rata payments to GTB shareholders, which was a horror story for common shareholders.

\section{Impact on $O B C$}

The merger had a favourable impact for $\mathrm{OBC}$ in terms of an increase in its reach and presence in South India and an addition of 1 million retail deposit holders to its total. With the bank focusing on retail in 2004-05, it utilised this opportunity to sell its retail products to GTB depositors. On the technology front, OBC was in the process of implementing Finacle, a core banking solution from Infosys, while GTB had already implemented the same. With both banks having the same technological platform, the transition of operations will be smooth.The profitability of the bank was bound take a hit on account of NPA provisioning of GTB. However, OBC had approximately Rs 16 billion unrealised profits on investments as of June 30, 2004, which could be utilised for reducing the impact of NPA provisioning.

The merger was announced on 27 th July, 2004, which will act as our ' $t$ '. 


\section{Event Based Analysis of the OBC stock price}

The 200-days regression analysis of OBC, with Bank Nifty, yields the following results -

\begin{tabular}{|l|l|}
\hline Alpha & 0.00098 \\
\hline Beta & 1.426 \\
\hline StdDev & 0.023 \\
\hline R-Squared & 0.716 \\
\hline
\end{tabular}

A high R-square, goes on to show that, OBC has a strong relation with Bank Nifty, and a high beta value indicates large volatility in the stock as compared to bank nifty.

\begin{tabular}{|l|l|l|}
\hline $\begin{array}{l}\text { Day from Merger } \\
\text { Announcement }\end{array}$ & $\begin{array}{l}\text { Abnormal Returns } \\
\text { (Market Model) }\end{array}$ & $\begin{array}{l}\text { Abnormal Returns (Market } \\
\text { Adjusted Model) }\end{array}$ \\
\hline+10 & $-0.41 \%$ & $-0.30 \%$ \\
\hline+9 & $-2.00 \%$ & $-1.17 \%$ \\
\hline+8 & $1.34 \%$ & $0.81 \%$ \\
\hline+7 & $-1.10 \%$ & $0.20 \%$ \\
\hline+6 & $0.21 \%$ & $0.00 \%$ \\
\hline+5 & $-0.25 \%$ & $-0.42 \%$ \\
\hline+4 & $-1.16 \%$ & $-0.77 \%$ \\
\hline+3 & $-0.35 \%$ & $-0.42 \%$ \\
\hline+2 & $-3.73 \%$ & $-2.67 \%$ \\
\hline+1 & $0.38 \%$ & $-0.25 \%$ \\
\hline Average & $-0.71 \%$ & $-0.50 \%$ \\
\hline Standard Deviation & $1.41 \%$ & $0.93 \%$ \\
\hline t-stat value at $\quad 95 \%$ & -1.59 & -1.70 \\
\hline $\begin{array}{l}\text { Significant No } \\
\text { confidence Interval? }\end{array}$ & & No \\
\hline
\end{tabular}

The t-stat seems to indicate that although OBC faced large abnormal returns, it is not significant at 95\% confidence interval, to discard the hypothesis. Subsequently, a comparison is made in the stock price belonging to post-announcement date and the pre-announcement date.

\begin{tabular}{|l|l|l|}
\hline $\begin{array}{l}\text { Day from Merger } \\
\text { Announcement }\end{array}$ & $\begin{array}{l}\text { Abnormal Returns } \\
\text { (Market Model) }\end{array}$ & $\begin{array}{l}\text { Abnormal Returns (Market } \\
\text { Adjusted Model) }\end{array}$ \\
\hline-1 & $0.95 \%$ & $1.25 \%$ \\
\hline-2 & $-1.15 \%$ & $-0.96 \%$ \\
\hline-3 & $-2.50 \%$ & $-1.16 \%$ \\
\hline-4 & $0.39 \%$ & $0.95 \%$ \\
\hline-5 & $1.20 \%$ & $1.46 \%$ \\
\hline-6 & $-0.47 \%$ & $0.10 \%$ \\
\hline-7 & $-0.06 \%$ & $0.97 \%$ \\
\hline-8 & $-0.53 \%$ & $-0.21 \%$ \\
\hline-9 & $0.59 \%$ & $0.76 \%$ \\
\hline-10 & $2.05 \%$ & $1.81 \%$ \\
\hline Average & $0.05 \%$ & $0.08 \%$ \\
\hline Standard Deviation & $1.29 \%$ & $1.01 \%$ \\
\hline t-stat value at & 0.12 & 0.23 \\
\hline $\begin{array}{l}\text { Significant ant } \\
\text { confidence Interval? }\end{array}$ & $\mathbf{N o}$ & $\mathbf{N o}$ \\
\hline
\end{tabular}


The analysis reveals that $\mathrm{OBC}$ didn't experience any abnormal returns, 10 days prior to the merger announcement.

\begin{tabular}{|l|l|l|}
\hline & $\begin{array}{l}\text { Abnormal Returns } \\
\text { (Market Model) }\end{array}$ & $\begin{array}{l}\text { Abnormal Returns (Market } \\
\text { Adjusted Model) }\end{array}$ \\
\hline On day of Announcement & $-2.83 \%$ & $-4.15 \%$ \\
\hline
\end{tabular}

However, on the day of announcement $\mathrm{OBC}$ took a hard hitting and faced an abnormal return. This indicates at the unfavourable response expressing dissatisfaction with the decision of merger.

\begin{tabular}{|l|l|l|}
\hline Event Window & CAR\%(market Model) & CAR\%(market Adjusted Model) \\
\hline$(-10,-1)$ & $0.48 \%$ & $4.98 \%$ \\
\hline$(-5,-1)$ & $-1.10 \%$ & $1.54 \%$ \\
\hline$(-10,10)$ & $-9.41 \%$ & $-4.17 \%$ \\
\hline$(-1,1)$ & $-1.50 \%$ & $-3.15 \%$ \\
\hline$(+1,+5)$ & $-5.11 \%$ & $-4.54 \%$ \\
\hline$(+1,+10)$ & $-7.07 \%$ & $-5.00 \%$ \\
\hline
\end{tabular}

It is observed that $\mathrm{OBC}$ had a large negative CAR post the merger announcement. Market experts attributed it to uncertainties over high NPA numbers on GTB's balance sheet. However, hardly any significant abnormal return in $(-10,-1)$ event window was observed in this specific case of merger. The $(+1,+10)$ abnormal returns has such a large bearing that the whole $(-10,+10)$ event window also took a beating.

\section{Event Based Analysis of the GTB stock price}

The 200-days regression analysis of GTB with Bank Nifty yields the following results -

\begin{tabular}{|l|l|}
\hline Alpha & -0.0001 \\
\hline Beta & 0.706 \\
\hline StdDev & 0.044 \\
\hline R-Squared & 0.098 \\
\hline
\end{tabular}

The R-square value is not encouraging, although, Bank Nifty is the best proxy, prevalent at that time for GTB. Also, the standard deviation values, stands at a large $4.5 \%$, indicating huge stock volatility.

\begin{tabular}{|l|l|l|}
\hline $\begin{array}{l}\text { Day from Merger } \\
\text { Announcement }\end{array}$ & $\begin{array}{l}\text { Abnormal Returns } \\
\text { (Market Model) }\end{array}$ & $\begin{array}{l}\text { Abnormal } \\
\text { Adjusted Model) }\end{array}$ \\
\hline+10 & $-16.64 \%$ & $-16.70 \%$ \\
\hline+9 & $18.84 \%$ & $18.29 \%$ \\
\hline+8 & $7.48 \%$ & $7.87 \%$ \\
\hline+7 & $2.50 \%$ & $1.62 \%$ \\
\hline+6 & $-3.70 \%$ & $-3.54 \%$ \\
\hline+5 & $-15.59 \%$ & $-15.45 \%$ \\
\hline+4 & $11.56 \%$ & $11.31 \%$ \\
\hline+3 & $11.44 \%$ & $11.51 \%$ \\
\hline+2 & $-5.79 \%$ & $-6.50 \%$ \\
\hline+1 & $-26.45 \%$ & $-25.99 \%$ \\
\hline Average & $-1.63 \%$ & $-1.76 \%$ \\
\hline Standard Deviation & $14.61 \%$ & $14.44 \%$ \\
\hline t-stat value & -0.35 & -0.38 \\
\hline $\begin{array}{l}\text { Significant } \\
\text { confidence Interval? }\end{array}$ & $\mathbf{N o}$ & $\mathbf{N o}$ \\
\hline
\end{tabular}


The $t$-stat seems to indicate, that although GTB faced abnormal returns, it is not significant at $95 \%$ confidence interval, to discard the hypothesis. The stock faced a huge standard deviation of nearly $15 \%$ during the postannouncement period. Now, a comparison is made in the stock prices of post-announcement dateand the preannouncement date.

\begin{tabular}{|c|c|c|}
\hline $\begin{array}{c}\text { Day from Merger } \\
\text { Announcement }\end{array}$ & $\begin{array}{c}\text { Abnormal Returns } \\
\text { (Market Model) }\end{array}$ & $\begin{array}{c}\text { Abnormal Returns (Market } \\
\text { Adjusted Model) }\end{array}$ \\
\hline-1 & $-20.05 \%$ & $-20.23 \%$ \\
\hline-2 & $-0.86 \%$ & $-0.97 \%$ \\
\hline-3 & $1.11 \%$ & $0.20 \%$ \\
\hline-4 & $-2.99 \%$ & $-3.35 \%$ \\
\hline-5 & $3.32 \%$ & $3.16 \%$ \\
\hline-6 & $11.65 \%$ & $11.28 \%$ \\
\hline-7 & $1.22 \%$ & $0.53 \%$ \\
\hline-8 & $-0.32 \%$ & $-0.52 \%$ \\
\hline-9 & $-3.16 \%$ & $-3.25 \%$ \\
\hline-10 & $-0.27 \%$ & $-0.08 \%$ \\
\hline Average & $-1.04 \%$ & $-1.32 \%$ \\
\hline Standard Deviation & $7.89 \%$ & $7.83 \%$ \\
\hline t-stat value & -0.41 & -0.53 \\
\hline Significant at 95\% confidence & $\mathbf{N o}$ & $\mathbf{N o}$ \\
\hline Interval? & & \\
\hline
\end{tabular}

It is seen that GTBhad started facing negative abnormal returns, 10 days prior to the merger announcement and it is significant at $95 \%$ confidence interval.

\begin{tabular}{|l|l|l|}
\hline & Abnormal Returns(Market Model) & $\begin{array}{l}\text { Abnormal Returns (Market } \\
\text { Adjusted Model) }\end{array}$ \\
\hline $\begin{array}{l}\text { On day of } \\
\text { Announcement }\end{array}$ & $-66.80 \%$ & $-65.86 \%$ \\
\hline
\end{tabular}

The stock, plummeted, by nearly $66 \%$, on the day of the announcement. The reason was simple. OBC, would only pay the residual amount after selling the assets to the common shareholders. As the deposits were already large, with no strong asset backing, common shareholders, hardly had anything to scrape for.

\begin{tabular}{|l|l|l|}
\hline & CAR\%(market Model) & CAR\%(market Adjusted Model) \\
\hline$(-10,-1)$ & $-10.35 \%$ & $-13.24 \%$ \\
\hline$(-5,-1)$ & $-19.48 \%$ & $-21.19 \%$ \\
\hline$(-10,10)$ & $-93.50 \%$ & $-96.67 \%$ \\
\hline$(-1,1)$ & $-113.30 \%$ & $-112.09 \%$ \\
\hline$(+1,+5)$ & $-24.83 \%$ & $-25.12 \%$ \\
\hline$(+1,+10)$ & $-16.35 \%$ & $-17.56 \%$ \\
\hline
\end{tabular}

The event window numbers, show an absolute bloodbath, post the announcement. 


\section{IDBI and IDBI Bank}

\section{Background and macro analysis of the deal}

The boards of both banks approved the scheme of amalgamation between the banks to create a merged entity that later boasted about Rs 78,000 crore of combined assets and manpower of over 4,000. Post-merger, the government continued to hold a majority stake in the merged entity. IDBI Ltd had systematically been preparing itself for the merger for which it had reduced its non-performing assets by creating a Rs 9,000 crore Stressed Assets Stabilisation Fund (SASF) and introduced a voluntary retirement scheme (VRS) to reduce manpower. On 20th Jan, 2005, the swap ratio for the merger of IDBI and IDBI Bank has been pegged at 100:142. The merger was announced on 29th July, 2004, which served as the ' $t$ ' for this deal and thereby the study.

Event Based Analysis of the IDBI stock price

The 200-days regression analysis of IDBI, with Bank Nifty, yields the following results -

\begin{tabular}{|l|l|}
\hline Alpha & 0.0004 \\
\hline Beta & 1.1445 \\
\hline StdDev & 0.0422 \\
\hline R-Squared & 0.3528 \\
\hline
\end{tabular}

The beta value shows IDBI, apparently, similar movements than Bank Nifty.

We now list down the post-announcement, abnormal returns of IDBI, to understand the impact of the merger phenomenon.

\begin{tabular}{|c|c|c|}
\hline $\begin{array}{c}\text { Day from Merger } \\
\text { Announcement }\end{array}$ & $\begin{array}{c}\text { Abnormal Returns } \\
\text { (Market Model) }\end{array}$ & $\begin{array}{c}\text { Abnormal Returns (Market } \\
\text { Adjusted Model) }\end{array}$ \\
\hline+10 & $3.16 \%$ & $3.07 \%$ \\
\hline+9 & $-5.01 \%$ & $-5.18 \%$ \\
\hline+8 & $0.80 \%$ & $0.84 \%$ \\
\hline+7 & $-4.90 \%$ & $-4.61 \%$ \\
\hline+6 & $-0.30 \%$ & $-0.48 \%$ \\
\hline+5 & $-0.39 \%$ & $0.04 \%$ \\
\hline+4 & $-0.43 \%$ & $-0.50 \%$ \\
\hline+3 & $5.99 \%$ & $5.94 \%$ \\
\hline+2 & $-1.05 \%$ & $-0.91 \%$ \\
\hline+1 & $0.42 \%$ & $0.41 \%$ \\
\hline Average & $-0.17 \%$ & $-0.14 \%$ \\
\hline Standard Deviation & $3.28 \%$ & $3.25 \%$ \\
\hline
\end{tabular}




\begin{tabular}{|c|c|c|}
\hline t-stat value & -0.16 & -0.13 \\
\hline Significant at 95\% & No & No \\
confidence Interval? & & \\
\hline
\end{tabular}

IDBI hardly faced any large abnormal returns during 10 days post the announcement. However, volatility was large, at around $3 \%$.

Let's now analyse the 10 days prior to the announcement.

\begin{tabular}{|c|c|c|}
\hline $\begin{array}{c}\text { Day from Merger } \\
\text { Announcement }\end{array}$ & $\begin{array}{c}\text { Abnormal Returns } \\
\text { (Market Model) }\end{array}$ & $\begin{array}{c}\text { Abnormal Returns (Market } \\
\text { Adjusted Model) }\end{array}$ \\
\hline-1 & $6.14 \%$ & $5.93 \%$ \\
\hline-2 & $-0.07 \%$ & $-0.53 \%$ \\
\hline-3 & $-1.76 \%$ & $-1.66 \%$ \\
\hline-4 & $-1.32 \%$ & $-1.24 \%$ \\
\hline-5 & $1.09 \%$ & $1.54 \%$ \\
\hline-6 & $3.64 \%$ & $3.83 \%$ \\
\hline-7 & $-3.47 \%$ & $-3.38 \%$ \\
\hline-8 & $-3.13 \%$ & $-2.93 \%$ \\
\hline-9 & $-0.38 \%$ & $-0.02 \%$ \\
\hline-10 & $0.12 \%$ & $0.23 \%$ \\
\hline Average & $0.08 \%$ & $0.50 \%$ \\
\hline Std Deviation & $2.96 \%$ & $2.92 \%$ \\
\hline t-stat value & 0.09 & 0.54 \\
\hline
\end{tabular}

IDBI, experienced small positive abnormal returns, 10 days prior to the announcement, however, not significant.

\begin{tabular}{|c|c|c|}
\hline & $\begin{array}{c}\text { Abnormal Returns } \\
\text { (Market Model) }\end{array}$ & $\begin{array}{c}\text { Abnormal Returns (Market } \\
\text { Adjusted Model) }\end{array}$ \\
\hline On day of Announcement & $3.35 \%$ & $3.71 \%$ \\
\hline
\end{tabular}

IDBI reacted very positively to the merger announcement. IDBI investors saw a lot of synergy and lower operation cost due to the merger. 


\begin{tabular}{|c|c|c|}
\hline Event Window & CAR\%(market Model) & CAR\%(market Adjusted Model) \\
\hline$(-10,-1)$ & $0.85 \%$ & $1.77 \%$ \\
\hline$(-5,-1)$ & $4.08 \%$ & $4.04 \%$ \\
\hline$(-10,10)$ & $2.49 \%$ & $4.12 \%$ \\
\hline$(-1,1)$ & $9.91 \%$ & $10.05 \%$ \\
\hline$(+1,+5)$ & $4.54 \%$ & $4.99 \%$ \\
\hline$(+1,+10)$ & $-1.71 \%$ & $-1.37 \%$ \\
\hline
\end{tabular}

The stock saw, a large positive, abnormal return, 5 days after the merger announcement. However, the abnormal returns, went bust, 10 days post the announcement.

Event Based Analysis of the IDBI Bank stock price

The 200-days regression analysis of IDBI Bank, with Bank Nifty, yields the following results -

\begin{tabular}{|l|l|}
\hline Alpha & 0.0007 \\
\hline Beta & 1.0696 \\
\hline StdDev & 0.0280 \\
\hline R-Squared & 0.5192 \\
\hline
\end{tabular}

Then a look is taken at abnormal data for upto 10 days post the merger announcement.

\begin{tabular}{|c|c|c|}
\hline $\begin{array}{c}\text { Day from Merger } \\
\text { Announcement }\end{array}$ & $\begin{array}{c}\text { Abnormal Returns } \\
\text { (Market Model) }\end{array}$ & $\begin{array}{c}\text { Abnormal Returns (Market } \\
\text { Adjusted Model) }\end{array}$ \\
\hline+10 & $-1.05 \%$ & $-1.04 \%$ \\
\hline+9 & $-1.47 \%$ & $-1.51 \%$ \\
\hline+8 & $-1.06 \%$ & $-0.99 \%$ \\
\hline+7 & $-3.46 \%$ & $-3.28 \%$ \\
\hline+6 & $0.29 \%$ & $0.26 \%$ \\
\hline+5 & $-3.11 \%$ & $-2.85 \%$ \\
\hline+4 & $1.84 \%$ & $1.86 \%$ \\
\hline+3 & $-1.17 \%$ & $-1.15 \%$ \\
\hline+2 & $-8.91 \%$ & $-8.79 \%$ \\
\hline+1 & $3.88 \%$ & $3.92 \%$ \\
\hline Average & $-1.42 \%$ & $-1.36 \%$ \\
\hline Standard Deviation & $3.42 \%$ & $3.37 \%$ \\
\hline t-stat value & -1.31 & -1.27 \\
\hline Significant at 95\% & No & No \\
\hline confidence Interval? & & \\
\hline
\end{tabular}


The t-stat seems to indicate that IDBI Bank didn't face any significant abnormal returns. However, it had a decent standard deviation, indicating at the volatility in the stock.

\begin{tabular}{|c|c|c|}
\hline $\begin{array}{c}\text { Day from Merger } \\
\text { Announcement }\end{array}$ & $\begin{array}{c}\text { Abnormal Returns } \\
\text { (Market Model) }\end{array}$ & $\begin{array}{c}\text { Abnormal Returns (Market } \\
\text { Adjusted Model) }\end{array}$ \\
\hline-1 & $0.83 \%$ & $0.78 \%$ \\
\hline-2 & $1.98 \%$ & $1.81 \%$ \\
\hline-3 & $-4.25 \%$ & $-4.15 \%$ \\
\hline-4 & $-2.19 \%$ & $-2.11 \%$ \\
\hline-5 & $-2.33 \%$ & $-2.06 \%$ \\
\hline-6 & $2.10 \%$ & $2.24 \%$ \\
\hline-7 & $1.46 \%$ & $1.55 \%$ \\
\hline-8 & $-0.31 \%$ & $-0.17 \%$ \\
\hline-9 & $-2.72 \%$ & $-2.50 \%$ \\
\hline-10 & $1.13 \%$ & $1.23 \%$ \\
\hline Average & $-0.57 \%$ & $-0.34 \%$ \\
\hline Standard Deviation & $2.36 \%$ & $2.21 \%$ \\
\hline T-stat Value & -0.76 & -0.48 \\
\hline Interval? & No & No \\
\hline
\end{tabular}

It is seen that IDBI Bank had faced negative abnormal returns, 10 days prior to the merger announcement.

\begin{tabular}{|c|c|c|}
\hline & $\begin{array}{c}\text { Abnormal Returns } \\
\text { (Market Model) }\end{array}$ & $\begin{array}{c}\text { Abnormal Returns (Market } \\
\text { Adjusted Model) }\end{array}$ \\
\hline On day of Announcement & $14.32 \%$ & $14.54 \%$ \\
\hline
\end{tabular}

The stock showed an exception abnormal return of nearly 15\%, on the date merger announcement, which seem to indicate that bank's common shareholder, absolutely liked the deal.

\begin{tabular}{|c|c|c|}
\hline Event Window & CAR\%(market Model) & CAR\%(market Adjusted Model) \\
\hline$(-10,-1)$ & $-4.29 \%$ & $-3.38 \%$ \\
\hline$(-5,-1)$ & $-5.95 \%$ & $-5.73 \%$ \\
\hline$(-10,10)$ & $-4.18 \%$ & $-2.42 \%$ \\
\hline$(-1,1)$ & $19.04 \%$ & $19.24 \%$ \\
\hline$(+1,+5)$ & $-7.46 \%$ & $-7.01 \%$ \\
\hline$(+1,+10)$ & $-14.21 \%$ & $-13.58 \%$ \\
\hline
\end{tabular}


The stock showed quite an abnormal return, around the merger announcement date, while it went bust during the next 10 day event window.

\section{IDBI and United Western Bank}

\section{Background and macro analysis of the deal}

Under the instruction of Reserve Bank of India, IDBI acquired the distressed United Western Bank, which the central bank had put under moratorium on September 2 2006. In the process, IDBI bested a long line of suitors, including Canara Bank, ICICI Bank, Citibank, Standard Chartered Bank, and a consortium of HDFC and the State Industrial Investment Corporation of Maharashtra. IDBI was adequately capitalised and it did not required pumping the money into United Western Bank, which had a net worth of Rs 70 crore. However, IDBI had to pay United Western Bank shareholders Rs 150.55 crore (Rs 1.5 billion) at Rs 28 a share, which worked out to a 31 per cent premium over United Western Bank's closing price of Rs 21.45 on the Bombay Stock Exchange on Tuesday. The valuation of assets and liabilities was binding on both banks, their shareholders and creditors. All employees of the distressed bank continued their service and be deemed to have been appointed in IDBI Bank at their current pay and perks, the draft scheme said. The merger was announced on 12th September, 2006, which will serve as the ' $t$ ' for our analysis.

Event Based Analysis of the IDBI stock price

The 200-days regression analysis of IDBI, with Bank Nifty, yields the following results -

\begin{tabular}{|l|l|}
\hline Alpha & -0.0027 \\
\hline Beta & 1.2722 \\
\hline StdDev & 0.0225 \\
\hline R-Squared & 0.7455 \\
\hline
\end{tabular}

IDBI shows a high R-square value, which shows high correlation with Bank Nifty.

We now list down the post-announcement, abnormal returns of IDBI, to understand the impact of the merger phenomenon.

The abnormal data for 10 days post the merger announcement is as follows:

\begin{tabular}{|l|l|l|}
\hline $\begin{array}{l}\text { Day from Merger } \\
\text { Announcement }\end{array}$ & $\begin{array}{l}\text { Abnormal Returns } \\
\text { (Market Model) }\end{array}$ & $\begin{array}{l}\text { Abnormal Returns (Market } \\
\text { Adjusted Model) }\end{array}$ \\
\hline+10 & $-2.14 \%$ & $-1.80 \%$ \\
\hline+9 & $0.69 \%$ & $0.51 \%$ \\
\hline+8 & $-1.62 \%$ & $-2.10 \%$ \\
\hline+7 & $0.12 \%$ & $0.26 \%$ \\
\hline+6 & $3.95 \%$ & $3.73 \%$ \\
\hline
\end{tabular}




\begin{tabular}{|l|l|l|}
\hline+5 & $0.95 \%$ & $0.49 \%$ \\
\hline+4 & $1.17 \%$ & $0.99 \%$ \\
\hline+3 & $2.53 \%$ & $2.32 \%$ \\
\hline+2 & $-5.63 \%$ & $-5.50 \%$ \\
\hline+1 & $7.77 \%$ & $8.58 \%$ \\
\hline Average & $0.78 \%$ & $0.75 \%$ \\
\hline Standard Deviation & $3.62 \%$ & $3.75 \%$ \\
\hline t-stat value at $95 \%$ & No & 0.63 \\
\hline $\begin{array}{l}\text { Significant } \\
\text { confidence Interval? }\end{array}$ & 0.68 & No \\
\hline
\end{tabular}

IDBI, hardly faced any large abnormal returns, during 10 days post the announcement. However, the volatility was large, at around $4 \%$.

The abnormal data for 10 days prior to the merger announcement is as follows:

\begin{tabular}{|l|l|l|}
\hline $\begin{array}{l}\text { Day from Merger } \\
\text { Announcement }\end{array}$ & $\begin{array}{l}\text { Abnormal Returns } \\
\text { (Market Model) }\end{array}$ & $\begin{array}{l}\text { Abnormal Returns (Market } \\
\text { Adjusted Model) }\end{array}$ \\
\hline-1 & $-1.72 \%$ & $-2.77 \%$ \\
\hline-2 & $0.12 \%$ & $-0.09 \%$ \\
\hline-3 & $-1.22 \%$ & $-1.74 \%$ \\
\hline-4 & $1.60 \%$ & $1.24 \%$ \\
\hline-5 & $1.05 \%$ & $0.84 \%$ \\
\hline-6 & $-0.60 \%$ & $-0.60 \%$ \\
\hline-7 & $-0.35 \%$ & $-0.29 \%$ \\
\hline-8 & $-1.07 \%$ & $-1.35 \%$ \\
\hline-9 & $3.04 \%$ & $2.98 \%$ \\
\hline-10 & $1.43 \%$ & $1.37 \%$ \\
\hline Average & $0.23 \%$ & $-0.23 \%$ \\
\hline Std Deviation & $1.51 \%$ & $1.70 \%$ \\
\hline t-stat value & 0.48 & -0.43 \\
\hline $\begin{array}{l}\text { Significant at 95\% } \\
\text { confidence Interval? }\end{array}$ & No & No \\
\hline
\end{tabular}

IDBI, showed no major abnormal return, 10 days prior to the announcement. 


\begin{tabular}{|l|l|l|}
\hline & $\begin{array}{l}\text { Abnormal Returns } \\
\text { (Market Model) }\end{array}$ & $\begin{array}{l}\text { Abnormal Returns (Market } \\
\text { Adjusted Model) }\end{array}$ \\
\hline $\begin{array}{l}\text { On day of } \\
\text { Announcement }\end{array}$ & $-2.47 \%$ & $-2.14 \%$ \\
\hline
\end{tabular}

IDBI, reacted negatively, to the merger announcement. IDBI was seen to overtaking a failed bank.

The abnormal data for the event windows defined is as follows:

\begin{tabular}{|l|l|l|}
\hline Event Window & CAR\%(market Model) & CAR\%(market Adjusted Model) \\
\hline$(-10,-1)$ & $2.28 \%$ & $-0.41 \%$ \\
\hline$(-5,-1)$ & $-0.17 \%$ & $-2.52 \%$ \\
\hline$(-10,10)$ & $7.61 \%$ & $4.94 \%$ \\
\hline$(-1,1)$ & $3.58 \%$ & $3.68 \%$ \\
\hline$(+1,+5)$ & $6.78 \%$ & $6.90 \%$ \\
\hline$(+1,+10)$ & $7.79 \%$ & $7.49 \%$ \\
\hline
\end{tabular}

The stock saw a large positive, abnormal return, 5 days after the merger announcement.

Event Based Analysis of the United Western Bank stock price

The 200-days regression analysis of United Western Bank, with Bank Nifty, yields the following results -

\begin{tabular}{|l|l|}
\hline Alpha & -0.0058 \\
\hline Beta & 0.9764 \\
\hline StdDev & 0.0475 \\
\hline R-Squared & 0.7455 \\
\hline
\end{tabular}

The R-square value is encouraging, and the beta value is very close to 1. Stock faced a large volatility of around $4.75 \%$.

We, now, take a look, at abnormal data for upto 10 days post the merger announcement.

\begin{tabular}{|l|l|l|}
\hline $\begin{array}{l}\text { Day from Merger } \\
\text { Announcement }\end{array}$ & $\begin{array}{l}\text { Abnormal Returns } \\
\text { (Market Model) }\end{array}$ & $\begin{array}{l}\text { Abnormal Returns (Market } \\
\text { Adjusted Model) }\end{array}$ \\
\hline+10 & $-1.38 \%$ & $-2.02 \%$ \\
\hline+9 & $0.28 \%$ & $-0.31 \%$ \\
\hline+8 & $3.46 \%$ & $2.89 \%$ \\
\hline+7 & $-0.46 \%$ & $-1.08 \%$ \\
\hline
\end{tabular}




\begin{tabular}{|l|l|l|}
\hline+6 & $-0.40 \%$ & $-0.98 \%$ \\
\hline+5 & $1.27 \%$ & $0.71 \%$ \\
\hline+4 & $2.40 \%$ & $1.81 \%$ \\
\hline+3 & $5.16 \%$ & $4.57 \%$ \\
\hline+2 & $3.98 \%$ & $3.36 \%$ \\
\hline+1 & $1.56 \%$ & $0.88 \%$ \\
\hline Average & $1.59 \%$ & $2.15 \%$ \\
\hline Standard Deviation & $2.14 \%$ & 1.45 \\
\hline t-stat value & 2.34 & No \\
\hline Significant & Yes & \\
\hline confidence Interval? & & \\
\hline
\end{tabular}

The t-stat seem to indicate, United Western Bank faced significant abnormal returns (as per market model), and 10 days post the merger announcement.

We, now, take a look, at abnormal data for 10 days prior to the merger announcement.

\begin{tabular}{|l|l|l|}
\hline $\begin{array}{l}\text { Day from Merger } \\
\text { Announcement }\end{array}$ & $\begin{array}{l}\text { Abnormal Returns } \\
\text { (Market Model) }\end{array}$ & $\begin{array}{l}\text { Abnormal Returns } \\
\text { (Market Adjusted Model) }\end{array}$ \\
\hline-1 & $8.33 \%$ & $7.82 \%$ \\
\hline-2 & $9.59 \%$ & $9.00 \%$ \\
\hline-3 & $10.62 \%$ & $10.07 \%$ \\
\hline-4 & $0.35 \%$ & $-0.23 \%$ \\
\hline-5 & $8.09 \%$ & $7.50 \%$ \\
\hline-6 & $-40.93 \%$ & $-41.54 \%$ \\
\hline-7 & $-0.15 \%$ & $-0.76 \%$ \\
\hline-8 & $-1.82 \%$ & $-2.40 \%$ \\
\hline-9 & $1.16 \%$ & $0.56 \%$ \\
\hline-10 & $-3.00 \%$ & $-3.60 \%$ \\
\hline Average & $-0.78 \%$ & $-1.36 \%$ \\
\hline Standard Deviation & $14.99 \%$ & $15.01 \%$ \\
\hline T-stat Value & -0.16 & -0.29 \\
\hline $\begin{array}{l}\text { Significant } \\
\text { confidence Interval? }\end{array}$ & No & $\mathbf{N o}$ \\
\hline
\end{tabular}


It was observed that United Western Bank faced negative abnormal returns, 10 days prior to the merger announcement, however is not significant. Also, the standard deviation was high at $15 \%$.

\begin{tabular}{|l|l|l|}
\hline & $\begin{array}{l}\text { Abnormal Returns } \\
\text { (Market Model) }\end{array}$ & $\begin{array}{l}\text { Abnormal Returns (Market } \\
\text { Adjusted Model) }\end{array}$ \\
\hline $\begin{array}{l}\text { On day of } \\
\text { Announcement }\end{array}$ & $-4.84 \%$ & $-5.47 \%$ \\
\hline
\end{tabular}

The stock showed an exceptional negative abnormal return of nearly $5 \%$, on the date merger announcement.

We, now, take a look, at abnormal data for the event windows defined above.

\begin{tabular}{|l|l|l|}
\hline Event Window & CAR\%(market Model) & CAR\%(market Adjusted Model) \\
\hline$(-10,-1)$ & $-7.77 \%$ & $-13.57 \%$ \\
\hline$(-5,-1)$ & $36.98 \%$ & $34.16 \%$ \\
\hline$(-10,10)$ & $3.26 \%$ & $-9.20 \%$ \\
\hline$(-1,1)$ & $5.04 \%$ & $3.22 \%$ \\
\hline$(+1,+5)$ & $14.36 \%$ & $11.33 \%$ \\
\hline$(+1,+10)$ & $15.86 \%$ & $9.85 \%$ \\
\hline
\end{tabular}

The stock showed quite apositive abnormal return, barring the $(-10,-1)$ event window.

\section{HDFC Bank and Centurion Bank}

Background and macro analysis of the deal

The merger between HDFC Bank and Centurion Bank, was the largest private banking deal, at that time.

The combined entity would have a nationwide network of 1,148 branches (the largest amongst private sector Banks) a strong deposit base of around Rs. 1,200 billion and net advances of around Rs. 850 billion. The balance sheet size of the combined entity would be over Rs. 1,500 billion.

Event Based Analysis of the HDFC Bank stock price

The 200-days regression analysis of IDBI, with Bank Nifty, yields the following results -

\begin{tabular}{|l|l|}
\hline Alpha & 0.0002 \\
\hline Beta & 0.8479 \\
\hline StdDev & 0.0171 \\
\hline R-Squared & 0.5487 \\
\hline
\end{tabular}

The R-square value, is at a decent 0.55, which shows a nice relationship of HDFC Bank, with the Bank Nifty. 
The post-announcement, abnormal returns of HDFC Bank, to understand the impact of the merger phenomenon is provided as below:

\begin{tabular}{|l|l|l|}
\hline $\begin{array}{l}\text { Day from Merger } \\
\text { Announcement }\end{array}$ & $\begin{array}{l}\text { Abnormal Returns } \\
\text { (Market Model) }\end{array}$ & $\begin{array}{l}\text { Abnormal Returns (Market } \\
\text { Adjusted Model) }\end{array}$ \\
\hline+10 & $0.66 \%$ & $0.50 \%$ \\
\hline+9 & $2.21 \%$ & $2.22 \%$ \\
\hline+8 & $-0.23 \%$ & $0.43 \%$ \\
\hline+7 & $0.20 \%$ & $0.51 \%$ \\
\hline+6 & $0.51 \%$ & $1.12 \%$ \\
\hline+5 & $1.65 \%$ & $2.79 \%$ \\
\hline+4 & $-1.88 \%$ & $-2.00 \%$ \\
\hline+3 & $2.46 \%$ & $2.67 \%$ \\
\hline+2 & $0.02 \%$ & $0.08 \%$ \\
\hline+1 & $1.57 \%$ & $1.46 \%$ \\
\hline Average & $0.72 \%$ & $0.98 \%$ \\
\hline Standard Deviation & $1.30 \%$ & $1.43 \%$ \\
\hline t-stat value & 1.74 & 2.16 \\
\hline $\begin{array}{l}\text { Significant } \\
\text { confidence Interval? }\end{array}$ & $\mathbf{N o}$ & Yes \\
\hline
\end{tabular}

HDFC Bank, showed significant positive abnormal returns (on the market adjusted model assumption).

The abnormal data for 10 days prior the merger announcement is provided as below:

\begin{tabular}{|l|l|l|}
\hline $\begin{array}{l}\text { Day from Merger } \\
\text { Announcement }\end{array}$ & $\begin{array}{l}\text { Abnormal Returns } \\
(\text { Market Model) }\end{array}$ & $\begin{array}{l}\text { Abnormal Returns (Market } \\
\text { Adjusted Model) }\end{array}$ \\
\hline-1 & $-1.86 \%$ & $-1.40 \%$ \\
\hline-2 & $1.92 \%$ & $2.24 \%$ \\
\hline-3 & $0.42 \%$ & $0.92 \%$ \\
\hline-4 & $0.77 \%$ & $0.76 \%$ \\
\hline-5 & $-0.58 \%$ & $-0.60 \%$ \\
\hline-6 & $-0.71 \%$ & $-1.11 \%$ \\
\hline-7 & $0.96 \%$ & $0.32 \%$ \\
\hline-8 & $1.95 \%$ & $1.55 \%$ \\
\hline-9 & $-1.18 \%$ & $-1.33 \%$ \\
\hline
\end{tabular}




\begin{tabular}{|l|l|l|}
\hline-10 & $1.64 \%$ & $2.35 \%$ \\
\hline Average & $0.33 \%$ & $0.03 \%$ \\
\hline Standard Deviation & $1.35 \%$ & $1.43 \%$ \\
\hline t-stat value & 0.78 & 0.07 \\
\hline $\begin{array}{l}\text { Significant, at 95\% confidence } \\
\text { interval }\end{array}$ & No & No \\
\hline
\end{tabular}

HDFC Bank, experience small positive abnormal returns, 10 days prior to the announcement, however not significant.

\begin{tabular}{|l|l|l|}
\hline & $\begin{array}{l}\text { Abnormal Returns } \\
\text { (Market Model) }\end{array}$ & $\begin{array}{l}\text { Abnormal Returns (Market } \\
\text { Adjusted Model) }\end{array}$ \\
\hline $\begin{array}{l}\text { On day of } \\
\text { Announcement }\end{array}$ & $-3.40 \%$ & $-3.35 \%$ \\
\hline
\end{tabular}

HDFC, reacted negatively, to the merger announcement.

The abnormal data for the event windows defined earlier is provided as below:

\begin{tabular}{|l|l|l|}
\hline Event Window & CAR\%(market Model) & CAR\%(market Adjusted Model) \\
\hline$(-10,-1)$ & $3.34 \%$ & $3.69 \%$ \\
\hline$(-5,-1)$ & $0.67 \%$ & $1.92 \%$ \\
\hline$(-10,10)$ & $7.11 \%$ & $10.12 \%$ \\
\hline$(-1,1)$ & $-3.69 \%$ & $-3.29 \%$ \\
\hline$(+1,+5)$ & $3.82 \%$ & $4.99 \%$ \\
\hline$(+1,+10)$ & $7.17 \%$ & $9.77 \%$ \\
\hline
\end{tabular}

The stock saw, a large positive, abnormal return, 10 days after the merger announcement, recovering from a large setback on the day of announcement.

Event Based Analysis of the Centurion Bank stock price

The 200-days regression analysis of Centurion Bank, with Bank Nifty, yields the following results

\begin{tabular}{|l|l|}
\hline Alpha & 0.0002 \\
\hline Beta & 0.2955 \\
\hline StdDev & 0.0230 \\
\hline R-Squared & 0.0656 \\
\hline
\end{tabular}


A low beta value shows that Centurion Bank, varies less wildly than the benchmark Bank Nifty.

The abnormal data for upto 10 days post the merger announcement is provided as below:

\begin{tabular}{|l|l|l|}
\hline $\begin{array}{l}\text { Day from Merger } \\
\text { Announcement }\end{array}$ & $\begin{array}{l}\text { Abnormal Returns } \\
(\text { Market Model) }\end{array}$ & $\begin{array}{l}\text { Abnormal Returns (Market } \\
\text { Adjusted Model) }\end{array}$ \\
\hline+10 & $1.87 \%$ & $1.08 \%$ \\
\hline+9 & $2.24 \%$ & $2.22 \%$ \\
\hline+8 & $-4.97 \%$ & $-1.97 \%$ \\
\hline+7 & $0.21 \%$ & $1.58 \%$ \\
\hline+6 & $-3.07 \%$ & $-0.33 \%$ \\
\hline+5 & $-3.23 \%$ & $1.98 \%$ \\
\hline+4 & $0.11 \%$ & $-0.52 \%$ \\
\hline+3 & $1.08 \%$ & $2.00 \%$ \\
\hline+2 & $-0.35 \%$ & $-0.15 \%$ \\
\hline+1 & $0.65 \%$ & $0.06 \%$ \\
\hline Average & $-0.55 \%$ & $0.59 \%$ \\
\hline Standard Deviation & $2.40 \%$ & $1.39 \%$ \\
\hline t-stat value & -0.72 & 1.35 \\
\hline $\begin{array}{l}\text { Significant } \\
\text { confidence Interval? }\end{array}$ & No & No \\
\hline
\end{tabular}

Due to the low beta value, we see that, on days, where market saw large fluctuations, the values from the two models differed, however, neither show significant abnormal return.

The abnormal data for upto 10 days prior to the merger announcement is provided as below:

\begin{tabular}{|l|l|l|}
\hline $\begin{array}{l}\text { Day from Merger } \\
\text { Announcement }\end{array}$ & $\begin{array}{l}\text { Abnormal Returns } \\
\text { (Market Model) }\end{array}$ & $\begin{array}{l}\text { Abnormal Returns (Market } \\
\text { Adjusted Model) }\end{array}$ \\
\hline-1 & $-0.64 \%$ & $1.43 \%$ \\
\hline-2 & $15.43 \%$ & $16.86 \%$ \\
\hline-3 & $-0.09 \%$ & $2.13 \%$ \\
\hline-4 & $-1.36 \%$ & $-1.48 \%$ \\
\hline-5 & $1.40 \%$ & $1.24 \%$ \\
\hline-6 & $0.57 \%$ & $-1.38 \%$ \\
\hline-7 & $0.98 \%$ & $-2.03 \%$ \\
\hline-8 & $3.13 \%$ & $1.20 \%$ \\
\hline
\end{tabular}




\begin{tabular}{|l|l|l|}
\hline-9 & $-4.57 \%$ & $-5.32 \%$ \\
\hline-10 & $-5.05 \%$ & $-1.85 \%$ \\
\hline Average & $1.16 \%$ & $1.08 \%$ \\
\hline Std deviation & $5.99 \%$ & $5.98 \%$ \\
\hline t stat value & 0.61 & 0.57 \\
\hline
\end{tabular}

It was observed that Centurion Bank had faced positive abnormal returns, 10 days prior to the merger announcement, however not significant at 95\% confidence interval.

\begin{tabular}{|l|l|l|}
\hline & $\begin{array}{l}\text { Abnormal Returns } \\
\text { (Market Model) }\end{array}$ & $\begin{array}{l}\text { Abnormal Returns (Market } \\
\text { Adjusted Model) }\end{array}$ \\
\hline $\begin{array}{l}\text { On day of } \\
\text { Announcement }\end{array}$ & $-14.16 \%$ & $-13.98 \%$ \\
\hline
\end{tabular}

Centurion Bank showed a large negative reaction to the merger announcement. The stock had already run up to the day of announcement. Hence, it might be highly possible, that market had already factored in the announcement, and the market didn't actually liked the initial details of the announcement.

The abnormal data for the event windows defined above is provided as below:

\begin{tabular}{|l|l|l|}
\hline Event Window & CAR\%(market Model) & CAR\%(market Adjusted Model) \\
\hline$(-10,-1)$ & $9.80 \%$ & $10.80 \%$ \\
\hline$(-5,-1)$ & $14.73 \%$ & $20.18 \%$ \\
\hline$(-10,10)$ & $-9.83 \%$ & $2.75 \%$ \\
\hline$(-1,1)$ & $-14.15 \%$ & $-12.49 \%$ \\
\hline$(+1,+5)$ & $-1.75 \%$ & $3.37 \%$ \\
\hline$(+1,+10)$ & $-5.47 \%$ & $5.94 \%$ \\
\hline
\end{tabular}

The stock did react negatively, around the announcement date. An important thing to note here is, it showed a large positive abnormal return, in run up to the announcement. An important thing to note here is, Market Model and Market Adjusted show a large difference, this because, beta of the stock is far from 1 .

\section{$5 \quad$ ICICI Bank and Bank of Rajasthan (BoR)}

\section{Background and macro analysis of the deal}

Under the deal, ICICI Bank gave 25 shares for 118 shares (1:4.72) of BoR. The swap indicated that ICICI bank would pay a 90 per cent premium over BoR stock's closing price of Rs 99.50 on the Bombay Stock Exchange just before the announcement date. The move to merge BoR with ICICI Bank came in the wake of regulatory pressure mounted on the Tayals (promoters), who according to Sebi, held nearly 55 per cent stake in the bank. 
Nearly 100 entities related to the Tayals were barred from dealing in securities. BoR had a market capitalisation of Rs 1,600 crore compared with ICICI Bank's Rs 99,000 crore. It had reported a net loss of Rs 44.7 crore for the quarter ended December 2009 on a revenue of Rs 344.83 crore. In terms of assets, ICICI Bank was around 25 times as large as BoR. In terms of branch network, BoR with 463 branches, was just less than quarter of ICICI Bank's network.

Analysts said that takeover would help ICICI Bank in expanding its footprint further, which is in line with its new-found branch-focused strategy. As most of BoR branches were concentrated in northern India, ICICI Bank would gain deeper access in these markets.

The merger was announced on 18th May, 2010, which would serve as the ' $t$ ' for our analysis.

Event Based Analysis of the ICICI Bank stock price

The 200-days regression analysis of ICICI Bank, with Bank Nifty, yields the following results -

\begin{tabular}{|l|l|}
\hline Alpha & -0.001 \\
\hline Beta & 1.272 \\
\hline StdDev & 0.010 \\
\hline R-Squared & 0.790 \\
\hline
\end{tabular}

The beta value, shows ICICI Bank, apparently, had larger movements than Bank Nifty. ICICI Bank shows a large R-square value, which shows Bank Nifty is an excellent measure for market returns.

We now list down the post-announcement, abnormal returns of ICICI Bank, to understand the impact of the merger phenomenon.

\begin{tabular}{|l|l|l|}
\hline $\begin{array}{l}\text { Day from Merger } \\
\text { Announcement }\end{array}$ & $\begin{array}{l}\text { Abnormal Returns } \\
\text { (Market Model) }\end{array}$ & $\begin{array}{l}\text { Abnormal Returns (Market } \\
\text { Adjusted Model) }\end{array}$ \\
\hline+10 & $-0.11 \%$ & $-0.88 \%$ \\
\hline+9 & $-0.23 \%$ & $-0.14 \%$ \\
\hline+8 & $0.25 \%$ & $0.34 \%$ \\
\hline+7 & $-2.12 \%$ & $-1.49 \%$ \\
\hline+6 & $2.28 \%$ & $2.76 \%$ \\
\hline+5 & $0.62 \%$ & $-0.14 \%$ \\
\hline+4 & $0.41 \%$ & $0.21 \%$ \\
\hline+3 & $0.98 \%$ & $0.80 \%$ \\
\hline+2 & $0.01 \%$ & $0.15 \%$ \\
\hline+1 & $-2.08 \%$ & $-3.24 \%$ \\
\hline Average & $0.00 \%$ & $-0.16 \%$ \\
\hline
\end{tabular}




\begin{tabular}{|l|l|l|}
\hline Standard Deviation & $1.32 \%$ & $1.55 \%$ \\
\hline t-stat value at 95\% & No & -0.33 \\
\hline $\begin{array}{l}\text { Significant } \\
\text { confidence Interval? }\end{array}$ & & No \\
\hline
\end{tabular}

ICICI Bank, hardly saw any abnormal returns, 10 days post the merger announcement.

We, now, take a look, at abnormal data for upto 10 days prior to the merger announcement.

\begin{tabular}{|l|l|l|}
\hline $\begin{array}{l}\text { Day from Merger } \\
\text { Announcement }\end{array}$ & $\begin{array}{l}\text { Abnormal Returns } \\
\text { (Market Model) }\end{array}$ & $\begin{array}{l}\text { Abnormal Returns (Market } \\
\text { Adjusted Model) }\end{array}$ \\
\hline-1 & $-0.20 \%$ & $-0.44 \%$ \\
\hline-2 & $0.74 \%$ & $0.17 \%$ \\
\hline-3 & $0.73 \%$ & $0.81 \%$ \\
\hline-4 & $-1.41 \%$ & $-1.20 \%$ \\
\hline-5 & $-0.14 \%$ & $-0.28 \%$ \\
\hline-6 & $0.04 \%$ & $1.09 \%$ \\
\hline-7 & $1.21 \%$ & $0.28 \%$ \\
\hline-8 & $-0.03 \%$ & $-0.09 \%$ \\
\hline-9 & $-0.65 \%$ & $-0.83 \%$ \\
\hline-10 & $-0.28 \%$ & $-0.76 \%$ \\
\hline Average & $0.00 \%$ & $-0.20 \%$ \\
\hline
\end{tabular}

The stock, didn't see any abnormal returns, even 10 days prior to the announcement date.

\begin{tabular}{|l|l|l|}
\hline & $\begin{array}{l}\text { Abnormal Returns } \\
\text { (Market Model) }\end{array}$ & $\begin{array}{l}\text { Abnormal Returns (Market } \\
\text { Adjusted Model) }\end{array}$ \\
\hline $\begin{array}{l}\text { On day of } \\
\text { Announcement }\end{array}$ & $-0.80 \%$ & $-0.96 \%$ \\
\hline
\end{tabular}

ICICI Bank, reacted slightly negatively, to the merger announcement.

The abnormal data for the event windows defined above is as follows:

\begin{tabular}{|l|l|l|}
\hline Event Window & CAR\%(market Model) & CAR\%(market Adjusted Model) \\
\hline$(-10,-1)$ & $0.02 \%$ & $-1.25 \%$ \\
\hline$(-5,-1)$ & $-0.28 \%$ & $-0.95 \%$ \\
\hline$(-10,10)$ & $-0.77 \%$ & $-3.84 \%$ \\
\hline
\end{tabular}




\begin{tabular}{|l|l|l|}
\hline$(-1,1)$ & $-3.08 \%$ & $-4.64 \%$ \\
\hline$(+1,+5)$ & $-0.05 \%$ & $-2.22 \%$ \\
\hline$(+1,+10)$ & $0.01 \%$ & $-1.63 \%$ \\
\hline
\end{tabular}

The stock saw, a negative, abnormal return, around the date of announcement. However, few days after the announcement, there was hardly any abnormal return left in the stock.

Event Based Analysis of the Bank of Rajasthan Bank stock price

The 200-days regression analysis of BOJ, with Bank Nifty, yields the following results -

\begin{tabular}{|l|l|}
\hline Alpha & 0.001 \\
\hline Beta & 0.973 \\
\hline StdDev & 0.030 \\
\hline R-Squared & 0.193 \\
\hline
\end{tabular}

The R-square value is not encouraging, although, Bank Nifty is the best proxy, prevalent at that time for Bank of Rajasthan.

We, now, take a look, at abnormal data for 10 days post the merger announcement.

\begin{tabular}{|l|l|l|}
\hline $\begin{array}{l}\text { Day from Merger } \\
\text { Announcement }\end{array}$ & $\begin{array}{l}\text { Abnormal Returns } \\
\text { (Market Model) }\end{array}$ & $\begin{array}{l}\text { Abnormal Returns (Market } \\
\text { Adjusted Model) }\end{array}$ \\
\hline+10 & $-0.48 \%$ & $-0.30 \%$ \\
\hline+9 & $0.63 \%$ & $0.72 \%$ \\
\hline+8 & $1.17 \%$ & $1.26 \%$ \\
\hline+7 & $-2.22 \%$ & $-2.19 \%$ \\
\hline+6 & $0.49 \%$ & $0.54 \%$ \\
\hline+5 & $2.04 \%$ & $2.21 \%$ \\
\hline+4 & $10.41 \%$ & $10.53 \%$ \\
\hline+3 & $10.32 \%$ & $10.44 \%$ \\
\hline+2 & $9.20 \%$ & $9.29 \%$ \\
\hline+1 & $23.84 \%$ & $24.05 \%$ \\
\hline Average & $5.54 \%$ & $5.65 \%$ \\
\hline Standard Deviation & $7.98 \%$ & $8.01 \%$ \\
\hline t-stat value & 2.20 & 2.23 \\
\hline $\begin{array}{l}\text { Significant } \\
\text { confidence Interval? }\end{array}$ & Yes & Yes \\
\hline
\end{tabular}


The t-stat, seem to indicate, that Bank of Rajasthan, faced large positive abnormal returns, post the announcement. The stock was locked, in upper circuit, in the initial few days.

The abnormal data for upto 10 days prior to the merger announcement is provided follows:

\begin{tabular}{|l|l|l|}
\hline $\begin{array}{l}\text { Day from Merger } \\
\text { Announcement }\end{array}$ & $\begin{array}{l}\text { Abnormal Returns } \\
(\text { Market Model) }\end{array}$ & $\begin{array}{l}\text { Abnormal Returns (Market } \\
\text { Adjusted Model) }\end{array}$ \\
\hline-1 & $4.22 \%$ & $4.34 \%$ \\
\hline-2 & $2.04 \%$ & $2.20 \%$ \\
\hline-3 & $-0.68 \%$ & $-0.59 \%$ \\
\hline-4 & $-3.23 \%$ & $-3.15 \%$ \\
\hline-5 & $-0.29 \%$ & $-0.18 \%$ \\
\hline-6 & $-5.83 \%$ & $-5.84 \%$ \\
\hline-7 & $1.35 \%$ & $1.54 \%$ \\
\hline-8 & $-5.52 \%$ & $-5.42 \%$ \\
\hline-9 & $16.24 \%$ & $16.36 \%$ \\
\hline-10 & $3.93 \%$ & $4.07 \%$ \\
\hline Average & $0.89 \%$ & $1.33 \%$ \\
\hline std deviation & $6.65 \%$ & $6.38 \%$ \\
\hline$t$ stat value & 0.42 & 0.66 \\
\hline
\end{tabular}

The stock hardly saw significant abnormal returns, 10 days prior to the announcement. Especially, two days prior to the announcement, which shows, there might be internal news brewing in the company, or the rumour mill might have started.

\begin{tabular}{|l|l|l|}
\hline & $\begin{array}{l}\text { Abnormal Returns } \\
\text { (Market Model) }\end{array}$ & $\begin{array}{l}\text { Abnormal Returns (Market } \\
\text { Adjusted Model) }\end{array}$ \\
\hline $\begin{array}{l}\text { On day of } \\
\text { Announcement }\end{array}$ & $20.28 \%$ & $20.40 \%$ \\
\hline
\end{tabular}

The stock, hit an upper $20 \%$ circuit, on the day of announcement, which shows, that investors, took it very positively, since the acquirer was one of the largest bank in the country.

We, now, take a look, at abnormal data for event windows defined above.

\begin{tabular}{|l|l|l|}
\hline Event Window & CAR\%(market Model) & CAR\%(market Adjusted Model) \\
\hline$(-10,-1)$ & $12.21 \%$ & $13.35 \%$ \\
\hline$(-5,-1)$ & $2.06 \%$ & $2.63 \%$ \\
\hline$(-10,10)$ & $87.87 \%$ & $90.29 \%$ \\
\hline
\end{tabular}




\begin{tabular}{|l|l|l|}
\hline$(-1,1)$ & $48.34 \%$ & $48.79 \%$ \\
\hline$(+1,+5)$ & $55.81 \%$ & $56.53 \%$ \\
\hline$(+1,+10)$ & $55.38 \%$ & $56.55 \%$ \\
\hline
\end{tabular}

All the event windows show exceptional, positive abnormal returns. On an average, the numbers are larger, in the post announcement period.

\section{Kotak Mahindra Bank and ING Vyasa Bank}

Background and macro analysis of the deal

It was the biggest banking merger of all times. Analysts believed that Kotak Mahindra bought at very attractive valuations. The transaction represents a price to book (P/B) value multiple of 2.1 times for ING Vysya. By this yardstick, Kotak has done well for itself. Other recent mergers such as HDFC Bank Ltd-Centurion Bank of Punjab and ICICI Bank Ltd-Bank of Rajasthan happened at P/B multiples as high as 4.8 times. While Kotak's shareholders would face a dilution of $17.9 \%$, the transaction would increase earnings per share (EPS) and book value per share from current levels. Compared with Kotak's current consolidated number estimates, the postmerger entity's EPS would be $6.3 \%$ higher for the current fiscal. Similarly, the book value per share was expected to rise $14.7 \%$.

Fundamentally, too, the banks seemed well-matched. While Kotak was a predominantly west India-based bank with $40 \%$ of its branches in Maharashtra and Gujarat alone, two-thirds of ING Vysya's branches were in the southern states, and that a majority of ING Vysya's branches were in urban and metro areas, another boost for Kotak. Second, Kotak's business is more urban-centric and tilted towards the retail customer. Close to half of its consolidated loan book goes towards financing the purchase of cars, commercial vehicles and homes. For ING, the retail book was about $17 \%$, and its area of strength was the small and medium enterprises segment (SME), which accounted for nearly $38 \%$ of its outstanding credit. A bigger and more diversified balance sheet made Kotak better placed to take advantage of the economic recovery when it strengthens.

The merger announcement date was 20th November, 2014, which will be our ' $t$ '.

Event Based Analysis of the Kotak Mahindra Bank stock price

The 200-days regression analysis of Kotak Mahindra, with Bank Nifty, yields the following results -

\begin{tabular}{|l|l|}
\hline Alpha & 0.0003 \\
\hline Beta & 0.7307 \\
\hline StdDev & 0.0128 \\
\hline R-Squared & 0.3677 \\
\hline
\end{tabular}

Beta value shows, Kotak Mahindra, has been less volatile as compared to the Bank Nifty.

We now list down the post-announcement, abnormal returns of Kotak Mahindra Bank, to understand the impact of the merger phenomenon. 


\begin{tabular}{|l|l|l|}
\hline $\begin{array}{l}\text { Day from Merger } \\
\text { Announcement }\end{array}$ & $\begin{array}{l}\text { Abnormal Returns } \\
\text { (Market Model) }\end{array}$ & $\begin{array}{l}\text { Abnormal Returns (Market } \\
\text { Adjusted Model) }\end{array}$ \\
\hline+10 & $-0.31 \%$ & $-0.47 \%$ \\
\hline+9 & $0.05 \%$ & $-0.05 \%$ \\
\hline+8 & $0.97 \%$ & $0.96 \%$ \\
\hline+7 & $-0.14 \%$ & $-0.13 \%$ \\
\hline+6 & $1.77 \%$ & $1.08 \%$ \\
\hline+5 & $-0.47 \%$ & $-0.50 \%$ \\
\hline+4 & $0.21 \%$ & $0.33 \%$ \\
\hline+3 & $-2.42 \%$ & $-2.02 \%$ \\
\hline+2 & $-0.88 \%$ & $-1.18 \%$ \\
\hline+1 & $1.84 \%$ & $1.26 \%$ \\
\hline Average & $0.06 \%$ & $-0.07 \%$ \\
\hline Standard Deviation & $1.27 \%$ & $1.04 \%$ \\
\hline t-stat value & 0.15 & -0.22 \\
\hline $\begin{array}{l}\text { Significant } \\
\text { confidence Interval? }\end{array}$ & No & No \\
\hline
\end{tabular}

Kotak Mahindra Bank, didn't show any significant abnormal returns, during this period.

\begin{tabular}{|l|l|l|}
\hline $\begin{array}{l}\text { Day from Merger } \\
\text { Announcement }\end{array}$ & $\begin{array}{l}\text { Abnormal Returns } \\
\text { (Market Model) }\end{array}$ & $\begin{array}{l}\text { Abnormal Returns (Market } \\
\text { Adjusted Model) }\end{array}$ \\
\hline-1 & $-0.24 \%$ & $-0.03 \%$ \\
\hline-2 & $-2.41 \%$ & $-2.48 \%$ \\
\hline-3 & $1.02 \%$ & $0.96 \%$ \\
\hline-4 & $-2.22 \%$ & $-2.37 \%$ \\
\hline-5 & $-0.78 \%$ & $-0.55 \%$ \\
\hline-6 & $0.83 \%$ & $0.56 \%$ \\
\hline-7 & $-0.68 \%$ & $-0.85 \%$ \\
\hline-8 & $-0.95 \%$ & $-0.79 \%$ \\
\hline-9 & $-0.48 \%$ & $-0.44 \%$ \\
\hline-10 & $0.62 \%$ & $0.31 \%$ \\
\hline Average & $-0.53 \%$ & $0.08 \%$ \\
\hline Standard Deviaton & $1.17 \%$ & $1.14 \%$ \\
\hline t-stat value & -1.43 & 0.21 \\
\hline
\end{tabular}


Kotak Mahindra Bank, didn't show any significant abnormal return, even before the announcement date.

\begin{tabular}{|l|l|l|}
\hline & $\begin{array}{l}\text { Abnormal Returns } \\
\text { (Market Model) }\end{array}$ & $\begin{array}{l}\text { Abnormal Returns (Market } \\
\text { Adjusted Model) }\end{array}$ \\
\hline $\begin{array}{l}\text { On day of } \\
\text { Announcement }\end{array}$ & $6.56 \%$ & $6.51 \%$ \\
\hline
\end{tabular}

Kotak, reacted very positively, to the merger announcement, and many of the reasons have been explained above.

We, now, take a look, at abnormal data for event windows defined above.

\begin{tabular}{|l|l|l|}
\hline Event Window & CAR\%(market Model) & CAR\%(market Adjusted Model) \\
\hline$(-10,-1)$ & $-5.30 \%$ & $-5.67 \%$ \\
\hline$(-5,-1)$ & $-4.63 \%$ & $-4.47 \%$ \\
\hline$(-10,10)$ & $1.89 \%$ & $0.11 \%$ \\
\hline$(-1,1)$ & $8.17 \%$ & $7.74 \%$ \\
\hline$(+1,+5)$ & $-1.72 \%$ & $-2.12 \%$ \\
\hline$(+1,+10)$ & $0.62 \%$ & $-0.72 \%$ \\
\hline
\end{tabular}

The stock saw, a large positive, abnormal return, around the merger announcement. However, the abnormal returns, went bust, 10 days post the announcement.

EventBased Analysis of the ING Vyasa Bank stock price

The 200-days regression analysis of ING Vyasa Bank, with Bank Nifty, yields the following results

\begin{tabular}{|l|l|}
\hline Alpha & 0.000 \\
\hline Beta & 0.525 \\
\hline StdDev & 0.016 \\
\hline R-Squared & 0.157 \\
\hline
\end{tabular}

The R-square value is not encouraging, although, Bank Nifty is the best proxy, prevalent at that time for ING VyasaBank. A low beta value shows that ING Vyasa Bank, varies less wildly than the benchmark Bank Nifty. 


\begin{tabular}{|c|c|c|}
\hline $\begin{array}{l}\text { Day from Merger } \\
\text { Announcement }\end{array}$ & $\begin{array}{l}\text { Abnormal Returns } \\
\text { (Market Model) }\end{array}$ & $\begin{array}{l}\text { Abnormal Returns (Market } \\
\text { Adjusted Model) }\end{array}$ \\
\hline+10 & $-0.57 \%$ & $-0.93 \%$ \\
\hline+9 & $2.14 \%$ & $1.90 \%$ \\
\hline+8 & $1.31 \%$ & $1.21 \%$ \\
\hline+7 & $1.29 \%$ & $1.24 \%$ \\
\hline+6 & $1.96 \%$ & $0.68 \%$ \\
\hline+5 & $0.15 \%$ & $0.01 \%$ \\
\hline+4 & $1.07 \%$ & $1.21 \%$ \\
\hline+3 & $-3.99 \%$ & $-3.37 \%$ \\
\hline+2 & $-0.16 \%$ & $-0.76 \%$ \\
\hline+1 & $-0.19 \%$ & $-1.29 \%$ \\
\hline Average & $0.30 \%$ & $-0.01 \%$ \\
\hline Standard Deviation & $1.78 \%$ & $1.60 \%$ \\
\hline t-stat value & 0.53 & -0.02 \\
\hline $\begin{array}{l}\text { Significant at } 95 \% \\
\text { confidence Interval? }\end{array}$ & No & No \\
\hline
\end{tabular}

Due to the low beta value, we see that, on days, where market saw large fluctuations, the values from the two models differed.

We, now, take a look, at abnormal data for 10 days prior to the merger announcement.

\begin{tabular}{|l|l|l|}
\hline $\begin{array}{l}\text { Day from Merger } \\
\text { Announcement }\end{array}$ & $\begin{array}{l}\text { Abnormal Returns } \\
\text { (Market Model) }\end{array}$ & $\begin{array}{l}\text { Abnormal Returns (Market } \\
\text { Adjusted Model) }\end{array}$ \\
\hline-1 & $3.61 \%$ & $3.91 \%$ \\
\hline-2 & $-1.26 \%$ & $-1.45 \%$ \\
\hline-3 & $-5.02 \%$ & $-5.20 \%$ \\
\hline-4 & $2.20 \%$ & $1.85 \%$ \\
\hline-5 & $4.00 \%$ & $4.35 \%$ \\
\hline-6 & $2.73 \%$ & $2.18 \%$ \\
\hline-7 & $-3.51 \%$ & $-3.87 \%$ \\
\hline-8 & $6.76 \%$ & $6.98 \%$ \\
\hline-9 & $4.61 \%$ & $4.61 \%$ \\
\hline-10 & $-1.03 \%$ & $-1.65 \%$ \\
\hline
\end{tabular}




\begin{tabular}{|l|l|l|}
\hline Average & $1.05 \%$ & $1.17 \%$ \\
\hline Standard Deviation & $3.96 \%$ & $4.02 \%$ \\
\hline t-stat value at 95\% & 0.84 & 0.92 \\
\hline $\begin{array}{l}\text { Significant } \\
\text { confidence Interval? }\end{array}$ & No \\
\hline
\end{tabular}

We see, that ING Vyasa Bank had faced positive abnormal returns, 10 days prior to the merger announcement.

\begin{tabular}{|l|l|l|}
\hline & $\begin{array}{l}\text { Abnormal Returns } \\
\text { (Market Model) }\end{array}$ & $\begin{array}{l}\text { Abnormal Returns (Market } \\
\text { Adjusted Model) }\end{array}$ \\
\hline $\begin{array}{l}\text { On day of } \\
\text { Announcement }\end{array}$ & $6.11 \%$ & $5.94 \%$ \\
\hline
\end{tabular}

ING Vyasa Bank showed a large negative reaction to the merger announcement. The stock had already run up to the day of announcement. Hence, it might be highly possible, that market had already factored in the announcement, and the market didn't actually liked the initial details of the announcement.

We, now, take a look, at abnormal data for event windows defined.

\begin{tabular}{|l|l|l|}
\hline Event Window & CAR\%(market Model) & CAR\%(market Adjusted Model) \\
\hline$(-10,-1)$ & $13.10 \%$ & $11.71 \%$ \\
\hline$(-5,-1)$ & $3.53 \%$ & $3.46 \%$ \\
\hline$(-10,10)$ & $22.20 \%$ & $17.54 \%$ \\
\hline$(-1,1)$ & $9.54 \%$ & $8.56 \%$ \\
\hline$(+1,+5)$ & $-3.13 \%$ & $-4.20 \%$ \\
\hline$(+1,+10)$ & $3.00 \%$ & $-0.10 \%$ \\
\hline
\end{tabular}

The stock did react very positively, around the announcement date. An important thing to note here is, it showed a large positive abnormal return, in run up to the announcement. However, the returns are not as large, post the announcement.

\section{Cumulative Analysis of the above 6 M\&As}

Now, as we have analysed the six banking M\&As, we now look at the cumulative figures of the numbers that have been calculated.

\subsection{Analysis of Acquiring Banks}

We, now, look at the cumulative values, of the acquiring banks, i.e., Oriental Bank of Commerce, IDBI, HDFC Bank, ICICI Bank, and Kotak Mahindra Bank 
Prior to the merger announcement

We, first analyse using the market model assumptions -

\begin{tabular}{|l|l|l|l|l|}
\hline $\begin{array}{l}\text { Days post the } \\
\text { Merger } \\
\text { announcement }\end{array}$ & $\begin{array}{l}\text { Average Abnormal } \\
\text { Returns }\end{array}$ & Std Deviation & t-stat value & $\begin{array}{l}\text { Signifant at } \\
95 \% \\
\text { Confidence } \\
\text { Interval? }\end{array}$ \\
\hline-1 & $0.51 \%$ & $2.95 \%$ & 0.42 & No \\
\hline-2 & $-0.14 \%$ & $1.50 \%$ & -0.23 & No \\
\hline-3 & $-0.55 \%$ & $1.47 \%$ & -0.92 & No \\
\hline-4 & $-0.36 \%$ & $1.49 \%$ & -0.59 & No \\
\hline-5 & $0.30 \%$ & $0.91 \%$ & 0.82 & No \\
\hline-6 & $0.45 \%$ & $1.66 \%$ & 0.67 & No \\
\hline-7 & $-0.40 \%$ & $1.68 \%$ & -0.58 & No \\
\hline-8 & $-0.63 \%$ & $1.65 \%$ & -0.93 & No \\
\hline-9 & $0.16 \%$ & $1.53 \%$ & 0.26 & Yes \\
\hline-10 & $0.93 \%$ & $0.92 \%$ & 2.48 & \\
\hline
\end{tabular}

We see, that, the results are positively significant, 10 days prior the announcement. On the other days, however, the results are very mixed, and nothing significant observation is implied.

We, now, look at the cumulative values, using the market adjusted model assumption, of the acquiring banks. This models assumes, the value of $\alpha$ as 0 , and $\beta$ as 1 .

\begin{tabular}{|l|l|l|l|l|}
\hline $\begin{array}{l}\text { Days post the } \\
\text { Merger } \\
\text { announcement }\end{array}$ & $\begin{array}{l}\text { Average } \\
\text { Abnormal } \\
\text { Returns }\end{array}$ & Std Deviation & t-stat value & $\begin{array}{l}\text { Signifant at } \\
95 \% \\
\text { Confidence } \\
\text { Interval? }\end{array}$ \\
\hline-1 & $0.35 \%$ & $4.61 \%$ & 0.17 & No \\
\hline-2 & $1.06 \%$ & $2.88 \%$ & 0.82 & No \\
\hline-3 & $-0.31 \%$ & $1.72 \%$ & -0.40 & No \\
\hline-4 & $-0.03 \%$ & $1.28 \%$ & -0.05 & No \\
\hline-5 & $-0.62 \%$ & $1.43 \%$ & -0.97 & No \\
\hline-6 & $0.31 \%$ & $1.09 \%$ & 0.64 & No \\
\hline-7 & $0.89 \%$ & $1.83 \%$ & 1.09 & No \\
\hline-8 & $-0.53 \%$ & $1.72 \%$ & -0.69 & No \\
\hline-9 & $-0.49 \%$ & $1.61 \%$ & -0.68 & No \\
\hline-10 & $-0.37 \%$ & $0.79 \%$ & -1.04 & No \\
\hline
\end{tabular}


The results from market adjusted are slightly different. There are no significant days, using this model assumption. Hence, none of the days violated the null hypothesis.

Day of merger announcement

Using the market model assumption -

\begin{tabular}{|l|l|l|l|}
\hline $\begin{array}{l}\text { Average Abnormal } \\
\text { Returns }\end{array}$ & Std Deviation & t-stat value & $\begin{array}{l}\text { Signifant at 95\% } \\
\text { Confidence } \\
\text { Interval? }\end{array}$ \\
\hline $0.07 \%$ & $4.02 \%$ & 0.04 & No \\
\hline
\end{tabular}

Using the market adjusted model assumption -

\begin{tabular}{|l|l|l|l|}
\hline $\begin{array}{l}\text { Average Abnormal } \\
\text { Returns }\end{array}$ & Std Deviation & t-stat value & $\begin{array}{l}\text { Signifant at 95\% } \\
\text { Confidence } \\
\text { Interval? }\end{array}$ \\
\hline $0.35 \%$ & $4.61 \%$ & 0.17 & No \\
\hline
\end{tabular}

In both the model assumptions, the values are not significantly positive, to reject the null hypothesis, hence, we can conclude that abnormal returns do take place for acquiring banks, on the day of announcement.

Post the merger announcement

\begin{tabular}{|l|l|l|l|l|}
\hline $\begin{array}{l}\text { Days post the } \\
\text { Merger } \\
\text { announcement }\end{array}$ & $\begin{array}{l}\text { Average Abnormal } \\
\text { Returns }\end{array}$ & Std Deviation & t-stat value & $\begin{array}{l}\text { Signifant at } \\
\mathbf{9 5 \%} \\
\text { Confidence } \\
\text { Interval? }\end{array}$ \\
\hline+10 & $0.14 \%$ & $1.74 \%$ & 0.20 & No \\
\hline+9 & $-0.71 \%$ & $2.51 \%$ & -0.70 & No \\
\hline+8 & $0.25 \%$ & $1.07 \%$ & 0.58 & No \\
\hline+7 & $-1.32 \%$ & $1.96 \%$ & -1.65 & No \\
\hline+6 & $\mathbf{1 . 4 0 \%}$ & $\mathbf{1 . 5 8} \%$ & $\mathbf{2 . 1 7}$ & Yes \\
\hline+5 & $0.35 \%$ & $0.86 \%$ & 1.00 & No \\
\hline+4 & $-0.28 \%$ & $1.11 \%$ & -0.62 & No \\
\hline 3 & $1.53 \%$ & $2.87 \%$ & 1.31 & Yes \\
\hline 2 & $-\mathbf{1 . 8 8} \%$ & $\mathbf{2 . 3 0} \%$ & $-\mathbf{2 . 0 0}$ & No \\
\hline 1 & $1.65 \%$ & $3.30 \%$ & 1.23 & \\
\hline
\end{tabular}

We see, that, the results are positively significant, 2 days post the announcement, and also 6 days post the announcement. On the other days, however, the results are very mixed, and nothing significant observation is implied. 
We, now, look at the cumulative values, using market adjusted model assumption, of the acquiring banks, i.e., Oriental Bank of Commerce, IDBI, HDFC Bank, ICICI Bank, and Kotak Mahindra Bank.

This models assumes, the value of $\alpha$ as 0 , and $\beta$ as 1 .

\begin{tabular}{|l|l|l|l|l|}
\hline $\begin{array}{l}\text { Days post the } \\
\text { Merger } \\
\text { announcement }\end{array}$ & $\begin{array}{l}\text { Average } \\
\text { Abnormal } \\
\text { Returns }\end{array}$ & Std Deviation & t-stat value & $\begin{array}{l}\text { Signifant at } \\
\text { 95\% } \\
\text { Confidence } \\
\text { Interval? }\end{array}$ \\
\hline+10 & $0.02 \%$ & $1.68 \%$ & 0.03 & No \\
\hline+9 & $-0.63 \%$ & $2.49 \%$ & -0.62 & No \\
\hline+8 & $0.21 \%$ & $1.16 \%$ & 0.45 & No \\
\hline+7 & $-0.88 \%$ & $1.96 \%$ & -1.10 & No \\
\hline+6 & $\mathbf{1 . 3 7 \%}$ & $\mathbf{1 . 6 1} \%$ & $\mathbf{2 . 0 8}$ & Yes \\
\hline+5 & $0.38 \%$ & $1.23 \%$ & 0.75 & No \\
\hline+4 & $-0.29 \%$ & $1.05 \%$ & -0.68 & No \\
\hline 3 & $1.55 \%$ & $2.77 \%$ & 1.37 & No \\
\hline 2 & $-1.67 \%$ & $2.14 \%$ & -1.92 & No \\
\hline 1 & $1.37 \%$ & $3.92 \%$ & 0.86 & No \\
\hline
\end{tabular}

The results from market adjusted are similar, however, with slight variation in numbers. We see, that, the results are positively significant to a large extent, 8 days post the announcement. On the other days, however, the results are very mixed, and nothing significant observation is implied.

\section{Event Based Study}

Now, we do a cumulative analysis of all the 6 acquiring banks, as per two models.

\section{Market Model}

\begin{tabular}{|l|l|l|l|l|}
\hline Period & CAAR $\%$ & Std Deviation & t-stat & Significant? \\
\hline$(-10,-1)$ & $0.28 \%$ & $3.00 \%$ & 0.23 & No \\
\hline$(-5,-1)$ & $-0.24 \%$ & $2.81 \%$ & -0.21 & No \\
\hline$(-10,10)$ & $1.48 \%$ & $6.23 \%$ & 0.58 & No \\
\hline$(-1,1)$ & $2.23 \%$ & $5.89 \%$ & 0.93 & No \\
\hline$(+1,+5)$ & $1.38 \%$ & $4.45 \%$ & 0.76 & No \\
\hline$(+1,+10)$ & $1.14 \%$ & $5.62 \%$ & 0.50 & No \\
\hline
\end{tabular}

\section{Market Adjusted Model}

\begin{tabular}{|l|l|l|l|l|}
\hline Period & CAAR $\%$ & Std Deviation & t-stat & Significant? \\
\hline$(-10,-1)$ & $0.52 \%$ & $3.84 \%$ & 0.27 & No \\
\hline$(-5,-1)$ & $-0.07 \%$ & $3.15 \%$ & -0.05 & No \\
\hline$(-10,10)$ & $1.88 \%$ & $5.56 \%$ & 0.68 & No \\
\hline$(-1,1)$ & $1.73 \%$ & $6.30 \%$ & 0.55 & No \\
\hline$(+1,+5)$ & $1.33 \%$ & $4.83 \%$ & 0.55 & No \\
\hline$(+1,+10)$ & $1.42 \%$ & $5.82 \%$ & 0.49 & No \\
\hline
\end{tabular}


We see no significant abnormal returns, in none of the event windows at 95\% confidence interval.

\subsection{Target Banks Analysis}

We, now, look at the cumulative values, of the acquiring banks, i.e., Global Trust Bank, IDBI Bank, Centurion Bank, Bank of Rajasthan, United Western Bank, and ING Vyasa Bank.

Prior to the merger announcement

We, first analyse using the market model assumptions -

\begin{tabular}{|l|l|l|l|l|}
\hline $\begin{array}{l}\text { Days post the } \\
\text { Merger } \\
\text { announcement }\end{array}$ & $\begin{array}{l}\text { Average Abnormal } \\
\text { Returns }\end{array}$ & Std Deviation & t-stat value & $\begin{array}{l}\text { Signifant at } \\
95 \% \\
\text { Confidence } \\
\text { Interval? }\end{array}$ \\
\hline-1 & $-0.62 \%$ & $10.01 \%$ & -0.15 & No \\
\hline-2 & $4.49 \%$ & $6.63 \%$ & 1.66 & No \\
\hline-3 & $0.28 \%$ & $5.61 \%$ & 0.12 & No \\
\hline-4 & $-1.20 \%$ & $2.11 \%$ & -1.40 & No \\
\hline-5 & $2.37 \%$ & $3.64 \%$ & 1.59 & No \\
\hline-6 & $-4.95 \%$ & $18.50 \%$ & -0.66 & No \\
\hline-7 & $0.22 \%$ & $1.92 \%$ & 0.29 & No \\
\hline-8 & $0.32 \%$ & $4.22 \%$ & 0.19 & No \\
\hline-9 & $1.93 \%$ & $7.77 \%$ & 0.61 & No \\
\hline-10 & $-0.72 \%$ & $3.14 \%$ & -0.56 & \\
\hline
\end{tabular}

We, now, look at the cumulative values, using the market adjusted model assumption, of the acquiring banks. This models assumes, the value of $\alpha$ as 0 , and $\beta$ as 1 .

\begin{tabular}{|l|l|l|l|l|}
\hline $\begin{array}{l}\text { Days post the } \\
\text { Merger } \\
\text { announcement }\end{array}$ & $\begin{array}{l}\text { Average } \\
\text { Abnormal } \\
\text { Returns }\end{array}$ & Std Deviation & t-stat value & $\begin{array}{l}\text { Signifant at } \\
95 \% \\
\text { Confidence } \\
\text { Interval? }\end{array}$ \\
\hline-1 & $-0.32 \%$ & $10.07 \%$ & -0.08 & No \\
\hline-2 & $4.58 \%$ & $7.08 \%$ & 1.58 & No \\
\hline-3 & $0.41 \%$ & $5.47 \%$ & 0.18 & No \\
\hline-4 & $-1.41 \%$ & $1.96 \%$ & -1.76 & No \\
\hline-5 & $2.34 \%$ & $3.42 \%$ & 1.67 & No \\
\hline
\end{tabular}




\begin{tabular}{|l|l|l|l|l|}
\hline-6 & $-5.51 \%$ & $18.53 \%$ & -0.73 & No \\
\hline-7 & $-0.51 \%$ & $2.15 \%$ & -0.58 & No \\
\hline-8 & $-0.06 \%$ & $4.14 \%$ & -0.03 & No \\
\hline-9 & $1.74 \%$ & $7.95 \%$ & 0.54 & No \\
\hline-10 & $-0.31 \%$ & $2.71 \%$ & -0.28 & No \\
\hline
\end{tabular}

The results are very mixed from both the models, and nothing significant observation is implied.

Day of merger announcement

Using the market model assumption -

\begin{tabular}{|l|l|l|l|}
\hline $\begin{array}{l}\text { Average Abnormal } \\
\text { Returns }\end{array}$ & Std Deviation & t-stat value & $\begin{array}{l}\text { Signifant at 95\% } \\
\text { Confidence } \\
\text { Interval? }\end{array}$ \\
\hline$-7.51 \%$ & $31.63 \%$ & -0.58 & No \\
\hline $\begin{array}{l}\text { Average Abnormal } \\
\text { Returns }\end{array}$ & Std Deviation & t-stat value & $\begin{array}{l}\text { Signifant at 95\% } \\
\text { Confidence } \\
\text { Interval? }\end{array}$ \\
\hline$-7.41 \%$ & $31.30 \%$ & -0.58 & No \\
\hline
\end{tabular}

In both the model assumptions, the values are not significant, to reject the null hypothesis, hence, we can conclude that abnormal returns do take place for target banks, on the day of announcement.

Post the merger announcement

\begin{tabular}{|l|l|l|l|l|}
\hline $\begin{array}{l}\text { Days post the } \\
\text { Merger } \\
\text { announcement }\end{array}$ & $\begin{array}{l}\text { Average Abnormal } \\
\text { Returns }\end{array}$ & Std Deviation & t-stat value & $\begin{array}{l}\text { Signifant at } \\
95 \% \\
\text { Confidence } \\
\text { Interval? }\end{array}$ \\
\hline+10 & $-3.04 \%$ & $6.76 \%$ & -1.10 & No \\
\hline+9 & $3.78 \%$ & $7.51 \%$ & 1.23 & No \\
\hline+8 & $1.23 \%$ & $4.19 \%$ & 0.72 & No \\
\hline+7 & $-0.36 \%$ & $2.21 \%$ & -0.40 & No \\
\hline+6 & $-0.74 \%$ & $2.20 \%$ & -0.82 & No \\
\hline+5 & $-3.08 \%$ & $6.51 \%$ & -1.16 & No \\
\hline+4 & $4.57 \%$ & $5.04 \%$ & 2.22 & Yes \\
\hline 3 & $3.80 \%$ & $6.25 \%$ & 1.49 & No \\
\hline 2 & $-0.34 \%$ & $6.52 \%$ & -0.13 & No \\
\hline 1 & $0.55 \%$ & $16.02 \%$ & 0.08 & \\
\hline
\end{tabular}


We see, that, the results are positively significant, 4 days post the announcement. On the other days, however, the results are very mixed, and nothing significant observation is implied.

We, now, look at the cumulative values, using market adjusted model assumption, of the target banks.

This modelassumes, the value of $\alpha$ as 0 , and $\beta$ as 1 .

\begin{tabular}{|l|l|l|l|l|}
\hline $\begin{array}{l}\text { Days post the } \\
\text { Merger } \\
\text { announcement }\end{array}$ & $\begin{array}{l}\text { Average } \\
\text { Abnormal } \\
\text { Returns }\end{array}$ & Std Deviation & t-stat value & $\begin{array}{l}\text { Signifant at } \\
\mathbf{9 5 \%} \\
\text { Confidence } \\
\text { Interval? }\end{array}$ \\
\hline+10 & $-3.32 \%$ & $6.63 \%$ & -1.23 & No \\
\hline+9 & $3.55 \%$ & $7.35 \%$ & 1.18 & No \\
\hline+8 & $1.71 \%$ & $3.49 \%$ & 1.20 & No \\
\hline+7 & $-0.35 \%$ & $2.13 \%$ & -0.40 & No \\
\hline+6 & $-0.56 \%$ & $1.58 \%$ & -0.87 & No \\
\hline+5 & $-2.23 \%$ & $6.73 \%$ & -0.81 & No \\
\hline+4 & $4.37 \%$ & $5.16 \%$ & 2.08 & Yes \\
\hline 3 & $4.00 \%$ & $6.05 \%$ & 1.62 & No \\
\hline 2 & $-0.59 \%$ & $6.57 \%$ & -0.22 & No \\
\hline 1 & $0.27 \%$ & $15.95 \%$ & 0.04 & No \\
\hline
\end{tabular}

The results from both the models are similar, however, with slight variation in numbers. The results are very mixed, and nothing significant observation is implied. The second model shows significant abnormal return 4 days after the announcement.

\section{Event Based Study}

Now, we do a cumulative analysis of all the 6 target banks, as per two models.

\section{Market Model Assumption}

\begin{tabular}{|l|l|l|l|l|}
\hline Period & CAAR $\%$ & Std Deviation & t-stat & Significant? \\
\hline$(-10,-1)$ & $2.12 \%$ & $10.73 \%$ & 1.18 & No \\
\hline$(-5,-1)$ & $-1.02 \%$ & $12.68 \%$ & -0.48 & No \\
\hline$(-10,10)$ & $0.51 \%$ & $65.32 \%$ & 0.05 & No \\
\hline$(-1,1)$ & $-10.11 \%$ & $61.88 \%$ & -0.98 & No \\
\hline$(+1,+5)$ & $3.73 \%$ & $30.54 \%$ & 0.73 & No \\
\hline$(+1,+10)$ & $4.47 \%$ & $29.47 \%$ & 0.91 & No \\
\hline
\end{tabular}


Market Adjusted Model

\begin{tabular}{|l|l|l|l|l|}
\hline Period & CAAR $\%$ & Std Deviation & t-stat & Significant? \\
\hline$(-10,-1)$ & $0.94 \%$ & $12.63 \%$ & 0.45 & No \\
\hline$(-5,-1)$ & $5.58 \%$ & $19.43 \%$ & 1.72 & No \\
\hline$(-10,10)$ & $0.38 \%$ & $59.84 \%$ & 0.04 & No \\
\hline$(-1,1)$ & $-7.46 \%$ & $55.17 \%$ & -0.81 & No \\
\hline$(+1,+5)$ & $5.82 \%$ & $27.68 \%$ & 1.26 & No \\
\hline$(+1,+10)$ & $6.85 \%$ & $26.61 \%$ & 1.54 & No \\
\hline
\end{tabular}

We see no significant abnormal returns, at 95\% confidence interval.

\section{CONCLUSION}

The study concludes with no abnormal returns in the event windows defined, for both the acquiring and the target banks, from the $6 \mathrm{M} \& \mathrm{~A}$ deals that have been studied. However, there have been significant abnormal returns on some days, prior and post the announcement date, for both the acquiring and the target bank. Among the 6 acquiring banks, the project could find significant average abnormal returns, 10 days prior and 6 days post the merger announcement. Also, significant Cumulative Average Abnormal Returns are found 10 days prior to the announcement. The project did not find any abnormal returns for the various event windows analysis.

Among the 6 target banks, abnormal returns are marked by large standard deviations, with returns, around the announcement date, ranging from a large $-70 \%$ to $+50 \%$. The study could find significant abnormal returns; 4 days post the merger announcement. However, no significant abnormal returns could be found for any of the event windows. The study also finds that abnormal returns gradually vanish, few days after the announcement, supporting the efficient market hypothesis of Fama et al. (1969).

A future scope of study, involves, analysing the target banks, in terms of profitability also. According to a research paper, low profitability target banks, have larger probability to fall, on the day of announcement. The study is limited to $6 \mathrm{M} \& \mathrm{~A}$ deals, and the abnormal returns do have a large standard deviation, especially in the target banks. A larger set of M\&A deals can be studied. As for its future scope of study Bank Nifty is used as the benchmark to calculate market returns, there can be more sophisticated benchmarks, which may be more particular to a stock. For e.g., for Global Trust Bank, if there was a small cap Bank Nifty, it could have been a better benchmark.

\section{REFERENCES}

1) Chatterjee, R., \& Kuenzi, A. (2001, June). Mergers and Acqusitions: The influence of methods of payment of bidder's share price. The Judge Institute of Management Studies - Working Paper0106, pp. 1-91.

2) Fernandez, P. (2003). Three Residual Income Valuation Methods and Discounted Cash Flow Valuation. Nevarra: Pricewaterhouse Coopers Chair of Finance.

3) Foerster, S. R., \& Sapp, S. G. (2006, February 15). Dividends and Stock Valuation: A Study From the Nineteenth to the Twenty-First Century. Retrieved March 2017, from Richard Ivey School of

Business:

https://www.ivey.uwo.ca/faculty/ssapp/Rese arch/Papers/SP_Valuation_Feb_15_2006.pdf 
4) Kalsie, A. (2014). Valuation of a Troubled Firm: A Case Study on Jet Airways. Manthan: Journal of Commerce and Management, 1(2), 110-131.

5) Kalsie, A., \& Arora, A. (2016). Equity Valuation of Public Sector Enterprises: Power Grid Corporation of India Limited \& ONGC Limited. Envision - International Journal of Commerce and Management, 10(1), 1-13.

6) Kalsie, A., \& Kalra, J. (2015). Mergers and Acquisitions : Impact on Operating Performance and Shareholder Wealth. Maharaja Agrasen Institute of Management Studies.

7) Kalsie, A., \& Kalra, J. K. (2015, June 1). Indian Takeovers: A Residual Income Approach to Analyse Value Creation for the Acquirer. Mudra : Journal of Finance and Accounting, 2(1), 1-18

8) Krishnamurti, C., \& Vishwanath, S. R. (2008). Mergers, Acquisitions and Corporate Restructuring. New Delhi: Sage.

9) Sherman, A. J., \& Hart, M. A. (2006). Mergers and Acquisitions from A to Z. AMACOM Div American Mgmt Assn, 2006. 